\title{
Kaunos Demeter Kutsal Alanı: Kült Uygulamaları
}

\author{
The Sanctuary of Demeter at Caunus: Rites
}

\section{Mustafa BULBA *}

Öz: Demeter Kutsal Alanı bir teras üzerine konumlanmıştır. Yapılan araştırmalarda burada hiçbir dönemde bir tapınak inşa edilmediği ve törenlerin açık havada gerçekleştirildiği tespit edilmiştir. Bir kaya bloğu, iki ocak ve birkaç kanal kutsal alanın özünü oluşturmaktadır. Hekatomnoslar Dönemi ile birlikte kült alanında ve uygulamalarında önemli değişiklikler olmuştur. Kaya bloğu ve ocaklar işlevlerini kaybetmiş, kanallar ise kullanılmaya devam etmiş olmalıdır. Teras üzerindeki kazılarda Geç Arkaik Dönem'den Hellenistik Dönem içlerine kadar buluntular ele geçmiştir. Önemli buluntu grupları olarak terrakottalar, hydrialar, khytralar, kandiller ve kernoslar sayılabilir. Buluntuların büyük çoğunluğu Hekatomnidler Dönemine aittir. Erken Hıristiyanlık Dönemi'nde bu alana Kaunos'un en erken ve en büyük kilisesi inşa edilmiştir.

Anahtar sözcükler: Kaunos, Demeter, Maussollos, Terrakotta, Seramik, Kandil, Kernos

Abstract: The Sanctuary of Demeter at Kaunos is on a terrace at Küçükkale. Researches have shown that on this terrace no temple was ever built. The sanctuary consisted of a rocky outcrop, two herds and some canals. From the time of the Hekatomnids this boulder and the herds seem to have lost their functions, although the canals were remained in use. On this terrace from the Archaic into the Hellenistic period were deicated votives, above all terracotta, Hydrien, Chythrai, lamps and Kernoi, which date predominantly from the time of the Hekatomnids. It was here on this terrace in the Early-Christian period that the earliest and largest church at Kaunos was built.

Keywords: Kaunos, Demeter, Maussollos, Terracottas, Vases, Lamps, Kernoi.

Kaunos Kenti'nde yer alan Demeter Kutsal Alanı üzerine şimdiye dek birçok araştırma yayımlanmıştır (Varkıvanç 1998, 87-96; Işık 2000, 229-40; Bulba 2006-2007, 109-114; Bulba 2010 649-667; Bulba 2011, 17-30; Doyran 2017, 1-14; Doyran 2017a, 59-65; Bulba 2018, 159-179; Bulba 2019, 31-41; Bulba 2019a [Baskıda]; Bulba 2019b [Baskıda]). Bu çalışmada ise kutsal alan üzerinde tespit edilen kalıntı ve buluntular ışığında gerçekleştirilmiş olması muhtemel kült uygulamalarının tespit edilmesine çalışılacaktır.

Buluntulara göre Kaunos'taki Demeter Terası (Fig. 1 ve 2) üzerindeki kült uygulamaları en geç Arkaik Dönem'de (sonlarında?) başlamış ve en geç Helenistik Dönem ortalarında sona ermiş olmalıdır. Seramik ve figürin buluntular ele geçmese de - eğer tesadüfen alanda düşüp de diğer buluntularla karışmadılarsa- üç adet Roma sikkesi (Zeynep Çizmeli-Öğün tarafından yayına hazırlanmaktadır) ve az sayıda kandil (Bulba 2019, 37-38) alanın düşük yoğunlukta da olsa Roma Dönemi'nde kutsallığını devam ettirdiğini ortaya koyabilir. Arkeolojik kalıntılar zayıf olsa da kentin en erken ve en büyük kilisesinin yapımı için bu alanın seçilmiş olması,

\footnotetext{
* Prof. Dr., Akdeniz Üniversitesi, Edebiyat Fakültesi, Arkeoloji Bölümü, mbulba@akdeniz.edu.tr. Antalya. https://orcid.org/0000-0002-7034-0575
} 
Hıristiyanlık evresine kadar terasın önemli bir kült merkezi olabileceğine işaret etmektedir (Zäh 2001, 403-413; Zäh 2001a, 111-116). Alanın yapılaşmaya uygun bir topografik yapıya sahip olmamasına ve burasının Hıristiyanlık Dönemi’nde oldukça küçülen kent merkezinden nispeten uzak olan bu teras üzerine kentin en erken ve en anıtsal kilisesinin inşa edilmiş olması ancak alanın erken dönemlerden beri kutsallığını halk arasında devam ettirmiş olmasıyla açıklanabilir. Sonuç olarak arkeolojik kalıntılara göre yaklaşık olarak MÖ 500 ile MÖ II. yüzyıl ortaları arasında (çok büyük yoğunluk Hekatomnoslar Dönemi olmak üzere) bu alanda kült uygulamalarının gerçekleşmiş olduğunu söylemek mümkündür. Bu durum büyük oranda diğer Demeter kültlerinde de karşımıza çıkmaktadır (Arkeolojik ve epigrafik kalıntılar doğrultusunda Anadolu ve yakın çevresindeki kutsal alanlardaki kullanım süreçleri için bk. Karataş 2014, 565 Fig. 65).

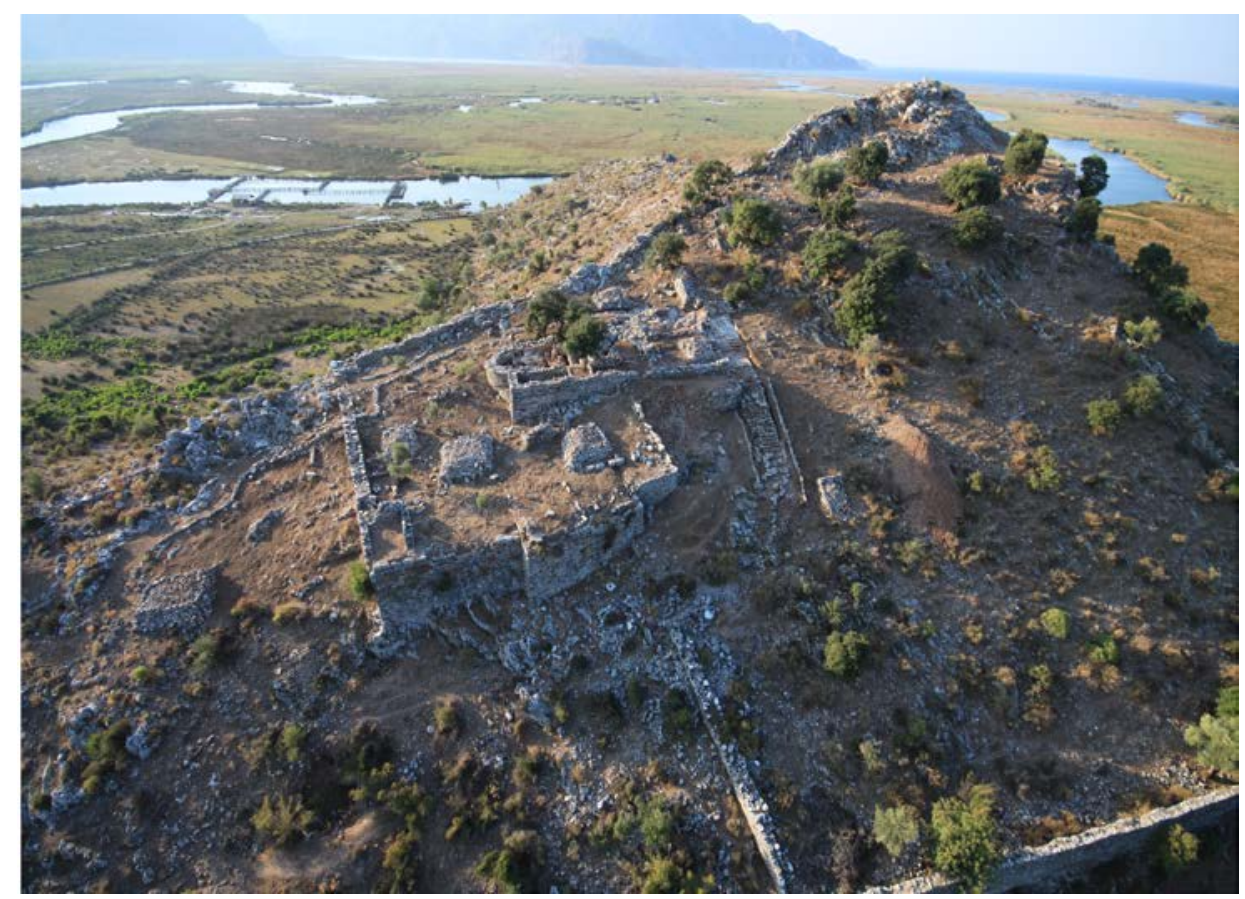

Fig. 1. Demeter Terası ve Kilise

Küçükkale üzerindeki bu noktaya kutsal alan yapılmasındaki en önemli etkeni alanın doğal yapısı oluşturur. Bunların başında bugün de kilisenin yaklaşık olarak ortasında korunmuş olan anakaya bloğu gelmektedir (Fig. 3). Bu kaya bloğunun hemen yakınlarındaki doğal kaya yarıkları da (Fig. 4) alanın seçilmesinde bir diğer faktörü oluşturmuş olmalıdırlar. Anakaya bloğuna kuzey yönde sonradan açılmış iki ocak ile doğal kaya yarıklarının yanında insan eliyle açılmış olması gereken kanallar ile kutsal alanın son haline kavuştuğu düşünülmektedir.

Demeter'e adanmış bu tür açık hava kutsal alanlarına Batı Anadolu'da, Girit'te ve Peloponnessos'ta rastlanmaktadır. Özellikle Anadolu ve Girit'teki kayalık alanlara yapılmış olan ve khthonik özellikler gösteren kutsal alanlar bilinmektedir (Karataş 2014, 350; Karataş [Baskıda]). Demeter Kutsal Alanları'nın ortak özelliklerinden birisini çok sayıda ele geçen figürinler, hydrialar, kandil buluntuları ve kernoslar oluşturmaktadır. Bunun yanında, bu kutsal alanlar genel olarak önemli mimari kalıntılara sahip olmayıp, ya üzerlerinde hiçbir yapı kalıntısı bulunmamakta ya da sadece basit yapılara ev sahipliği yapmaktadırlar. Batı Anadolu için sadece Bergama ve Milet'deki kutsal alanlar istisna olarak kabul edilebilir. Schipporeit'a göre Milet ve Bergama'daki kutsal alanların anıtsallığı bu kültlere Helenistik Dönem'den itibaren erkeklerin de dahil olmasıyla ilgilidir ve anıtlar erkekler tarafindan finanse edilmiş olmalıdır (Schipporeit 2013, 434). 


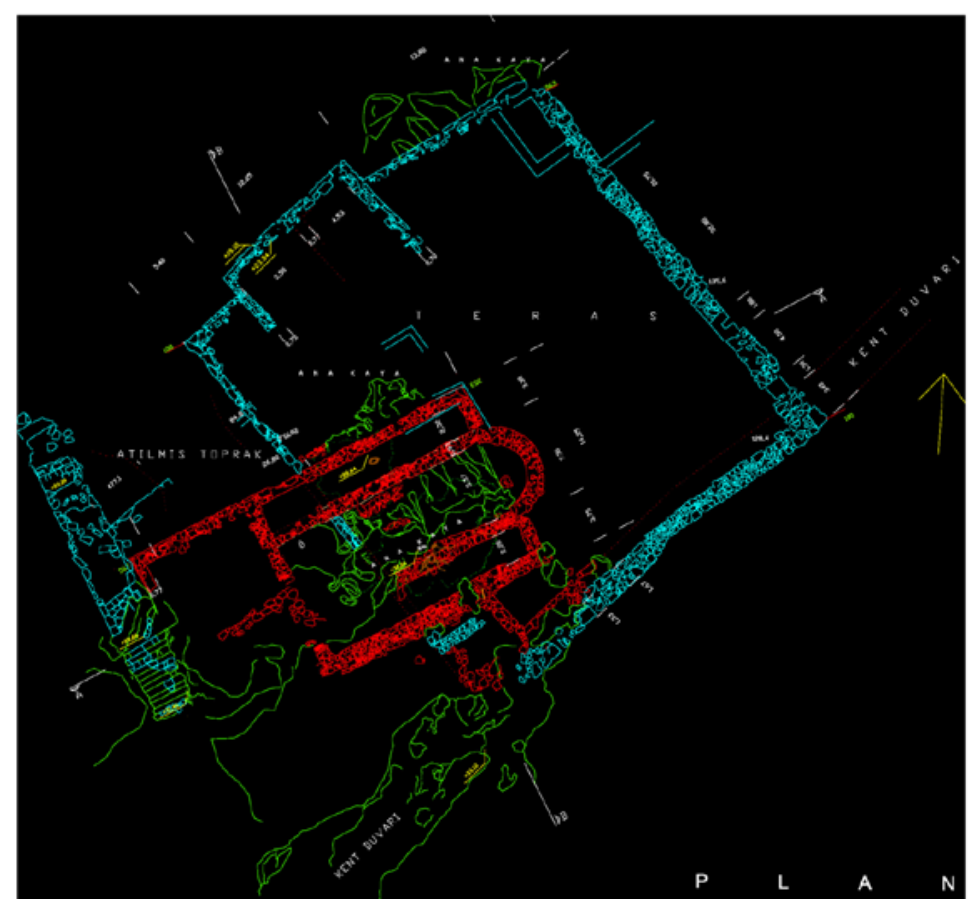

Doç. Dr. Nevzat Oğuz OZZER (Mimar Sinan Güzel Sanatlar Universitesi. Mimarlık Fakültesi)/ Yrd. Doç. Dr. Yasemen SAY ÖZER.( Yıldız Teknik Üniversitesi. Mimarlık Fakültesi) Serdar Akerdem (Total Station Ölçümler) / Fatma TANIŞ (Ölçümler-CAD çizimler) / Ege OZER (CAD çizimler)

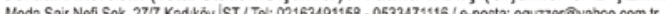

Fig. 2. Alanın olası evreleri

Kaunos'taki Demeter Kutsal Alanı'nı kült uygulamaları yönünden iki ana evreye ayırmak olasıdır. Hekatomnoslar Dönemi'nde, olasılıkla da Karia'nın en güçlü satrapı Maussollos’un yönetiminde, kült alanında büyük değişiklikler yapılmıştır. Öncelikle kutsal alanın sınırları bugünkü sınırlarına ulaşmış ve öncesi evrelere ait bazı uygulamalar ise iptal edilmiş ya da değişime uğramıştır.

Hekatomnoslar Dönemi'nde gerçekleştirilen kült uygulamalarına ilişkin değişikliklerin en belirgin uygulaması anakaya bloğunda karşımıza çıkmaktadır. Demeter ile kaya bloklarının ilişkisi efsanelerde her ne kadar yas tutma sırasında bir kayalığın üzerine oturmasıyla karşımıza çıksa da, Kaunos'taki kutsal alanın merkezi konumunda olan bu kaya bloğu ile Demeter'in başlangıçta bir ilişkisi olmamalıdır. Bu alandaki kült geleneği büyük ihtimalle çok daha eskiye giden bir özelliğe sahipti (Demeter'in en eski ve en iyi bilinen kutsal mekanlarından biri olan Eleusis'te de durum farklı değildi. Myken döneminden Arkaik Çă̆’a kadar bu alandaki kutsal kayalar açıkta durmakta ve kutsal alanın kalbini oluşturmaktaydı. Bk. Bruns 1960, 100-111; Rubensohn 1955, 1-49). Elimizde bu alanın başlangıçtan itibaren Demeter'e adandığına dair veri mevcut değildir. Bununla birlikte söz konusu alanın Arkaik Dönem'den itibaren kullanımda olduğunu çok az sayıda figürin parçası ortaya koymaktadır. Mimari anlamda teras duvarlarının bir bölümünün de göreceli olarak bu tarihe verilebilir olması da bunu desteklemektedir. Demeter Kutsal Alanları'nın yukarıda bahsedilen ortak buluntu gruplarının Kaunos'ta bu dönem için söz konusu olmaması nedeniyle Arkaik Dönem ve eğer varsa öncesinin kült uygulamalarını başka bir tanrı/tanrıça ya da tanrılarda/tanrıçalarda aramak gerekmektedir. Kayaların kutsal kabul edilmesi ve onlara anikonik tanrı özelliği verilerek tapınılması geleneği çok erken dönemlere kadar geri gitmektedir. Kron, 'Argoi lithoi' diye adlandırılan, primitif olarak anikonik tanrı betimlemesini sembolize eden bu kayaların dinsel anlamlarının zamanla kısmen unutulduğu ve o günün ihtiyaçlarına göre özellikler kazandığını düşünmektedir ('Argoi lithoi' doğal kayalar olabileceği gibi, zemine sabitlenmiş ham kayalar ya da işlenmemiş doğal taşlar da 
olabilir: Kron 1992a, 56-70. Ancak yazarın da vurguladığı gibi, genellikle yazıtlı belgeler eksik olduğu için bunların yorumlanmaları zor ve spekülatiftir).

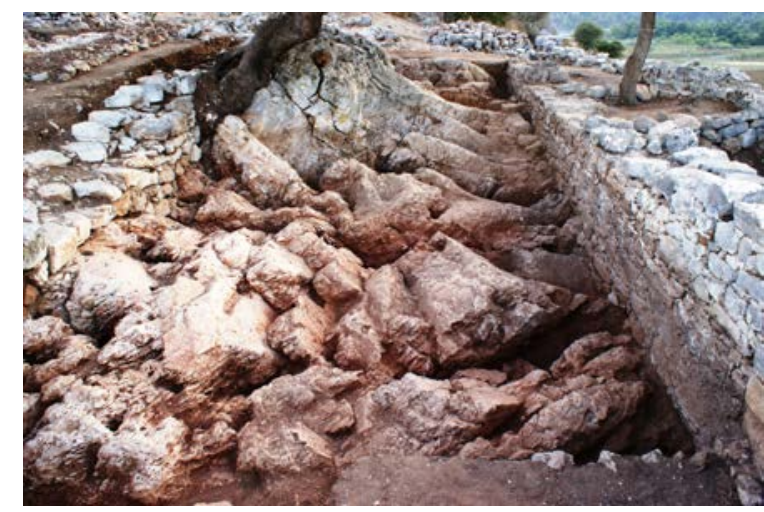

Fig. 3. Anakaya bloğu ve kilise orta nefinin içerisindeki kayalık zemin

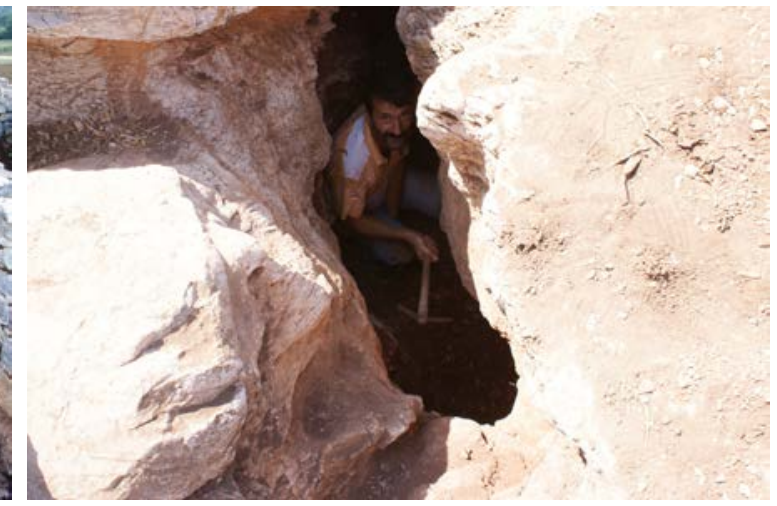

Fig. 4. Doğal Kaya Oyuğu

Kült alanlarının merkezinde bu tarz anakaya bloğunun ya da dikme kayaların yer aldığı kutsal alanlar Kaunos'a yabancı değildir ve kentte en az iki alanda daha karşımıza çıkmaktadır (Diler 1995, 9-20; Diler 2000, 53-77; Diler 2017a, 165-194). Kaunos’taki kaya bloğu, zaman içerisinde önceki evrelerdeki anlamını yitirmiş ve sadece Demeter'in üzerine oturduğu sembolik bir kaya haline dönüşmüş olmalıdır. Kutsal alan en geniş sınırlarına ulaştığında batı peribolosu artık, tam ortasından olmasa da anakaya bloğunu ikiye bölecek şekilde üzerinden geçmektedir. Ayrıca yine batıda yer alan ocağın işlevini kaybetmiş olduğu anlaşılmaktadır. Olasılıkla aynı durum içerisinde çok az sayıda buluntu ele geçse de doğudaki ocak için de geçerlidir. Burada az sayıda buluntu ele geçmesinin nedeni eğim nedeniyle gerçekleşen karışma olmalıdır. Kutsal alandaki genişleme ve yeniden düzenleme faaliyetlerinden sonra da Doğu Roma Dönemi'ne kadar burasının açık hava kutsal alanı olarak kaldığı, ayrıca doğal ve insan eliyle açılmış kanalların kullanılmaya devam ettiği anlaşılmaktadır. Anakaya ile ocakların işlevleri ise büyük oranda ya da tamamen sonlanmış ve kutsal alan yeni bir kimliğe kavuşmuş olmalıdır (Kutsal alanlardaki değişiklikler alışılmadık bir durum değildir. Lukania'daki Herakleia antik kentinin bulunduğu alana Geç Arkaik Dönem'de khthonik tanrılara adanan bir kutsal alan yapılmıştır. Herakleia kenti 433-32 y1lında kurulduğunda bu kutsal alan şehre dahil edilmiş ve Demeter'e adanmıştır. Bk. Otto 2001, 191-196. Efes Artemis kutsal alanında da aynı durum olasılıkla söz konusudur. Muss 2005, 133-151). Efes’teki Artemis Kutsal Alanı'ndaki en eski tanrının Artemis olmadığını düşünmektedir. Burada eski, yerli bir Anadolu tanrısının yanında (olasılıkla Leto ile eş tutulmuştur) ele geçen kemiklerin, kandil ve hydriaların varlığı nedeniyle Demeter'e de tapınılmış olabileceği ve thesmophoria şenliklerinin kutlanmış olabileceği ileri sürülmüsşür (bk. Muss 1983, 92; 2001, 153-168; 2005, 133-151; Bammer 1998, 44; Forstenpointner 2001, 69 dn. 76).

Bu kaya bloğunun Hekatomnoslar Dönemi öncesine ait fonksiyonu hakkında değişik teoriler ileri sürmek mümkünse de elimizde bunu destekleyecek arkeolojik veri yok denecek kadar azdır. Kayalık alanlar kanalları ve oyuklarıyla birlikte Demeter ve yer altı arasında bağlantı kurmaya yaramaktadır. Demeter'in yanında Hades ile kızı Persephone ile de ilişkili olmaları nedeniyle bunlar kutsal kabul edilmiştir (Miles 1998, 20). Bu bağlamda yukarıda da vurgulandığı üzere ilk olarak akla Demeter gelse de, Kaunos'ta onun kutsal alanlarına özgü verilerimizin eksikliği nedeniyle Hekatomnoslar Dönemi öncesi kült sistemini yerel khthonik tanrı ya da tanrılarda aramak daha doğru olacaktır. Anakaya bloğu üzerinden batı peribolos duvarının geçirilmesi özellikle erken dönem inanç sistemini yok etmek amacıyla yapılmış olmalıdır. Aynı şekilde ocakların da kullanıma kapatılması da erken dönem inanç sistemini unutturmaya yönelik 
olmalıdır. Daha sonraki evrelerde yapılan düzenlemelerle anakaya bloğu da olasılıkla anikonik tanrı olma özelliğini kaybederek, etrafındaki kaya yarıkları yoluyla kızının yeraltından çıkmasını beklerken yas tutmak için üzerinde oturduğu sembolik bir kayalık olarak algılanmaya devam etmiş olabilir.

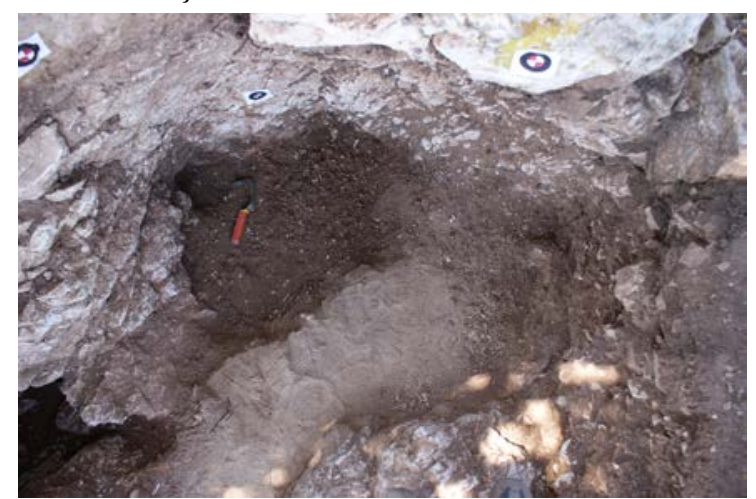

Fig. 5. 1 no'lu ocak, kazı sırasında

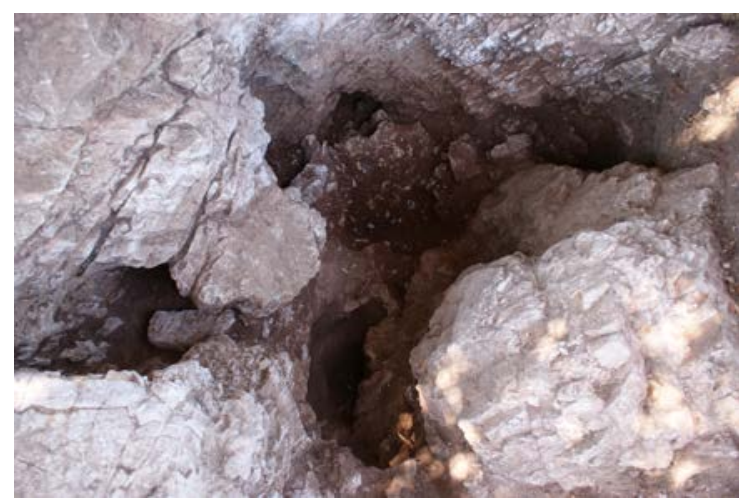

Fig. 6. 1 no'lu ocak, kazı sonrası

Kaya bloğunun kuzeyinde yer alan ve yan yana açılmış olan iki ocak (Fig. 5-9), bağımsız kaya kütlesi ve anakayaya oyulmuş kanallar ile birlikte kutsal alanın erken döneminin en önemli unsurlarını oluştururlar. Ocaklarla ilgili kültler olasılıkla en erken kült uygulamalarının da merkezindeydi. Ateş, tapınak kavramı henüz gerçek anlamına ulaşmadan ocaklarla birlikte kutsal kabul ediyor olmalıydı ve Paleolitik dönemlerden itibaren içerisinde ateş yanan ocaklarda sunular ve adaklar yapılmaktaydı (Burkert 2011, 96).

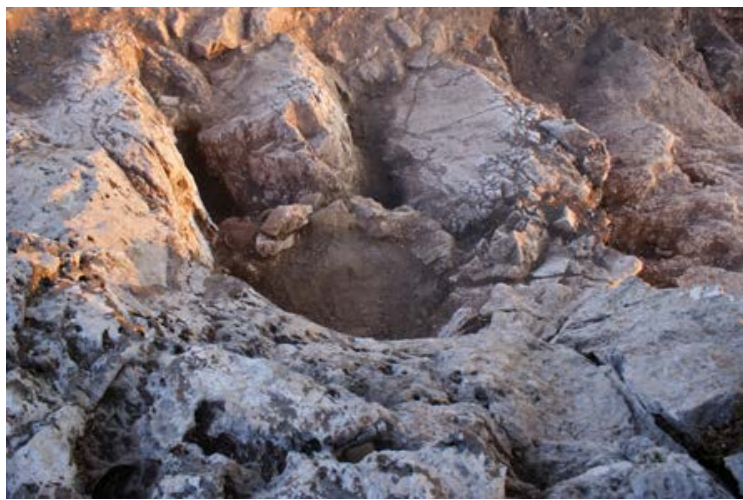

Fig. 7. 2 no'lu ocak, kazı sırasında

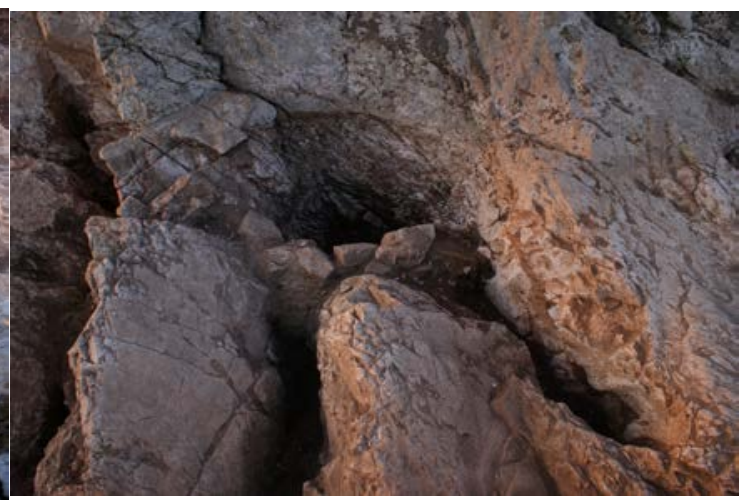

Fig. 8. 2 no'lu ocak, kazıdan sonra

$\mathrm{Bu}$ ocakların zeminin altına gelecek şekilde açılmış olmaları khthonik tanrı inancına işaret etmektedir. Bu tarz zemine açılmış çukurlar ve ocaklar özellikle ölü kültlerinde görülmektedir. Bu kültlerde bir altar dikilmeyip, yere çukur açılarak sıvı sunular içine akıtılmaktaydı (Örneğin Odysseus, Kirke'nin yönlendirmesiyle dünyanın kenarında yere bir çukur açarak üç kere libasyon yaptıktan sonra Hades ve Persephone'ye dualar ederek bir koç ve koyun kurban eder ve kanlarını bu çukura akıtır. Daha sonra ruhlar buraya toplanarak susuzluklarını giderirler. Kurban hayvanları da çukurun hemen yanında yakılmaktadır [Hom. Od. X. 517-537; XI. 2350]). Anakaya bloğuna kuzey yönde yan yana yapılmış iki ocakta da çok ince, içerisinde yanmış ahşap ve başka organik madde kalıntısı olmayan kül tabakaları tespit edilmiştir. Bu ocaklarda neler yakıldığına yönelik analizler yapılmamıştır. Bununla birlikte güçlü bir ateş olmadı̆̆ı gerek taşlarda yanık izleri olmamasından, gerekse yanmış odun vb. organik madde kalmamasından anlaşılmaktadır. 


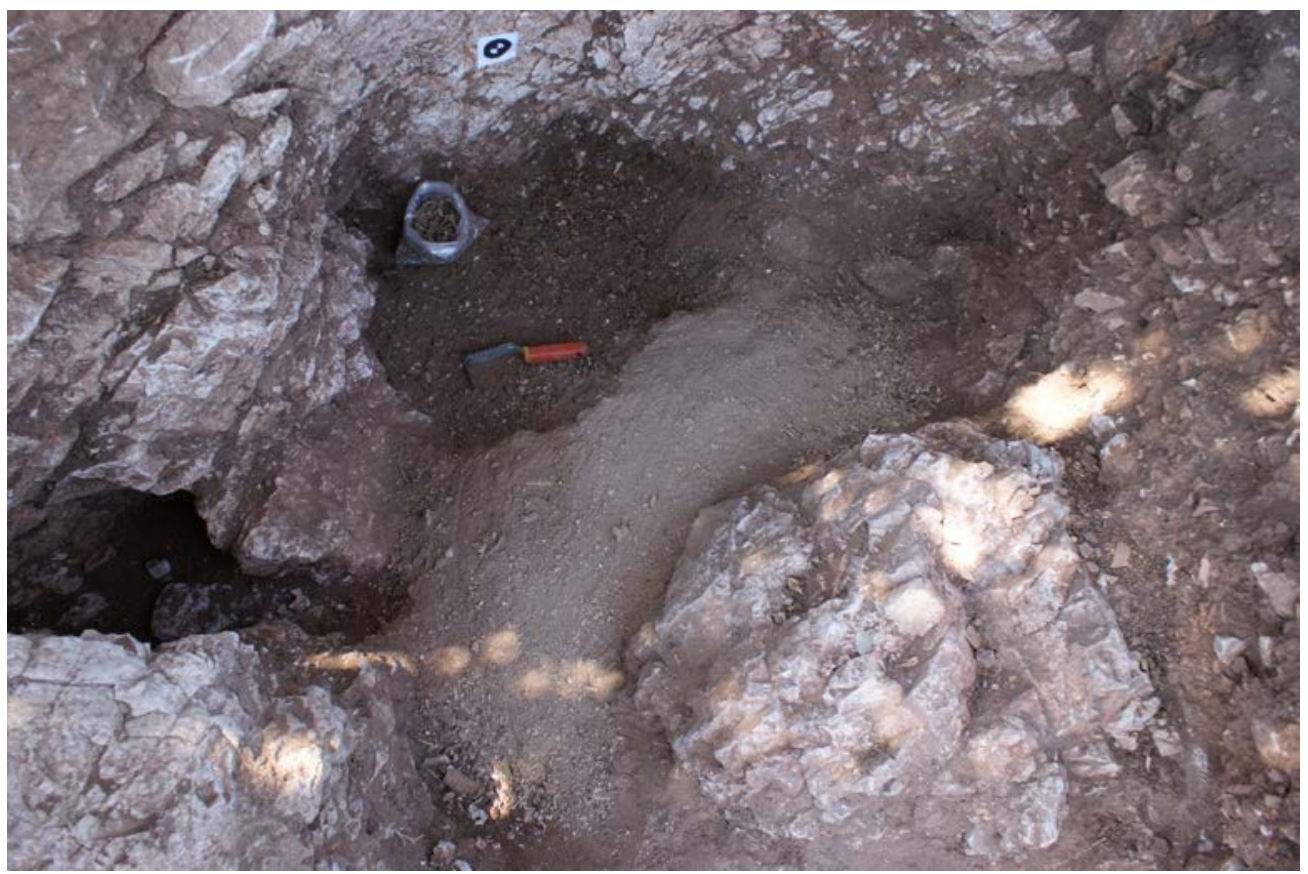

Fig. 9. 1 no’lu ocak, sunu çukuru, kemikler ve küller

Sembolik de olsa ateş, $1 \mathrm{~S} 1$ ve 1şık vermesiyle, koruyucu ve yakıcı özelliğiyle insanlar için kültsel anlamda her zaman çok önemli bir role sahip olmuştur. Burkert, ateşin aynı zamanda kötü ruhlardan da koruyucu bir özelliği olduğunu düşünmektedir. Ayrıca ocak bir tanrıça olarak (Hestia) Hellen kültüründe karşımıza çıkmaktadır ve yine en eski tapınaklar ocak-ev şeklindeydiler (Burkert 2011, 100). İçerisinde ateşin önemli role sahip olduğu birçok kült ve bu kültlere ait törenler mevcuttur (Burkert 2011, 102).

Söz konusu ocaklar içerisindeki çok ince yoğunluktaki küller, ancak sembolik olarak ateş yakılmış olabileceğini ve geriye kalıntı bırakmayan ot, saman vb. ürünlerin yakılmış olabileceğini göstermektedir. İkinci ve daha güçlü olasılık ise sadece tütsü yakılarak buhur ya da mür benzeri tütsülerin yapılmış olabileceğidir. En geç MÖ 700 yıllarından itibaren buhur ve mür gibi tütsü malzemeleri Fenikeliler aracılı̆̆ıyla Güney Arabistan'dan Ege dünyasına taşınmıştır (Arkeolojik veri olarak en erken Mısır'da kültlerle bağlantılı olarak MÖ 3. bin ortalarından itibaren buhur ve mürün kullanıldığı, MÖ 2. bin ortalarından itibaren ise kültsel amaçlı olarak kullanıldıklarına yönelik veriler mevcuttur. Örneğin Plutarkhos'un (de Is. et Os. 79-80) belirttiğine göre Demeter ile benzer özelliklere sahip Mısır tanrısı İsis için günde üç defa mür sunulmaktaydı. Asurlular, Persler, Fenikeliler bu tütsüleri tapınaklarında sıklıkla 'kötü ruhları' kovmak ya da güzel koku yoluyla tanrıları onurlandırmak için kullanmışlardır. Yine Herodotos olasılıkla miktarı abartsa da Perslerin Hellenlere karşı ikinci seferlerine çıkmadan önce Delos Apollon Tapınağı'nda 300 talanta $(1$ talanton $=25,6 \mathrm{~kg}$ ) buhur yaktığına aktarmaktadır (bk. Martinetz, Karlheinz \& Janzen 1989, 103-123). Ticaret ile birlikte bu kült uygulamalarının yaygınlaştığı kabul edilmektedir. Buhur ve mür tütsüleri öncelikle Aphrodite ve Adonis kültleri ile ilişkilendirilmektedir (bk. Martinetz, Lohs \& Janzen 1989, 111; Burkert 2011, 88-90). Özellikle Adonis'in Mür ağacından doğmasına yönelik efsaneler ve Aphrodite'nin yakışıklı delikanlıyı Persephone'ye teslim ettikten sonra Adonis'i geri vermek istememesi, sonucunda da Adonis'in yılın 2/3'ünü Aphrodite ile geçirmesi ilginçtir. Bu efsane hem Aphrodite-Adonis, ilişkisini hem de aynı zamanda Persephone'yi de içermesi bakımından Demeter kutsal alanlarındaki Aphrodite ilişkisini de ortaya koyuyor olabilir (Efsane için bk. Burkert 2011, 73). Aphrodite kültlerinin yanında Demeter Kutsal Alanları'nda da sunulan kansız adaklar içinde tütsünün 
yer aldığına dair çok sayıda epigrafik ve arkeolojik belge mevcuttur (Karataş 2014, 52 ve 62-64. Karataş, Pausanias'ın zeytin ağacı dalları ile buğdayın yakılmasıyla tütsü yapıldığını ve sıvı sunu olarak şarap akıtıldığını aktarmasından hareket ederek aynı durumun Neandria kutsal alanı için de geçerli olabileceğini düşünmektedir. Belki benzer bir durum Kaunos için de söz konusu olabilir. Yine Mytilene' deki ocak altarda buğday ve arpa kalıntıları tespit edilmiştir (bk. Cronkite 1997, 45). Ancak yine de bir kez daha bu ocakların faaliyette olduğu dönemlerde Kaunos'ta Demeter tapınımına ait buluntu konteksi olmadığı ve yerel bir tanrıçaya tapınılma ihtimalinin daha yüksek olduğu göz önünde tutulmalıdır).

$\mathrm{Bu}$ iki ocak ilk etapta birbirlerine benzese de detaylarda bazı farklılıklara sahiptirler. Özellikle doğudaki ocak aynı zamanda sıvı sunuların da yapılmış olması gereken ayrı bir bölümü mevcuttur. Ocağın doğu bölümünde, üst kısımda küçük bir havuz oluşturulmuş ve bu havuzun akıtacağının olduğu yere olasılıkla akmanın yoğunluğunu azaltmak için bir taş parçası sıkıştırılmıştır (Fig. 9). Bu durumda bu ocakta hem yakma, hem sıvı sunular birlikte gerçekleştirilmiş olmalıdır. Batıdaki ocakta ise böyle bir yapı karşımıza çıkmaz. Ortak noktaları ise içlerinde kül bulunması, özellikle üst kısımlarda yoğun kemik ele geçmesidir. Bunların seviyelerinin yürüme düzeyinden daha aşağıda olmaları ve ateş ile bağlantılı oldukları için eschara ya da bomos olabilecekleri de ihtimal dahilindedir. Antik kaynaklarda nispeten sik olarak bu iki tanımlama şu durumlarda karşımıza çıkmaktadır:

1) Ölüler, kahramanlar, ya da khthonik tanrılar için yere açılmış çukur altarlar. Bunların içlerinde genellikle kurban hayvanlarının etleri yakılmaktaydı;

2) Diğer tanrılar için hayvan etlerinin pişirildiği altar bölümü;

3) Yine khthonik tanrılar için ancak yere oyulmadan, tanrıların khthonik özelliklerine vurgu yapmak için adakların eğilerek bırakılmak zorunda olduğu çok alçak altarlar (Robert 1939, 185).

Bunlardan özellikle ilki Kaunos'taki ocaklara yakın olmakla birlikte ocakların asıl amaçlarının hayvanları ya da etlerini yakmak olmadığı düşünüldügünde, bunları eschara ya da bomos olarak adlandırmanın doğru olmayacağı, bunların basit sıvı sunular, sembolik ateşler ya da tütsüler için açı1mış olduklarını düşünmek olası görünmektedir.

Kaunos'taki uygulamalarda domuzların tam olarak hangi amaca yönelik olarak ve nasıl kurban edildiklerini ve nerelere bırakıldıkları, kemiklerinin neden bu ocakların olduğu alana getirilip bırakıldığını tespit etmek mümkün olmamıştır. Bunun yanında yakılan ateşin ya da yapılan tütsünün kullanım amacı da belirsizdir. İki ocakta da iki tarafa doğru genişleyen kanal biçimli yapılmış 'kollar' mevcuttur ve kuzey bölümde sonlanmaktadır. Ocaklar özensiz işçilikli bir duvar ile kabaca daire oluşturacak şekildedir. Doğudaki ocak, eğimli yapısı nedeniyle kısmen karışmış olması gereken az sayıda adak buluntusuna da ev sahipliği yaparken batıdaki ocağın bilinçli bir şekilde kapatıldığı, en üstüne arka bölümü yukarı gelecek şekilde Kıbrıs kaynaklı kireç taşı heykelciklerden birinin yerleştirildiği ve sonrasında bir daha kullanılmadığı görülmektedir.

Anakaya bloğu, bu bloğun kuzey yönünde ve yan yana açılmış iki ocak dışında, Kaunos'ta gerçekleştirilmiş olması muhtemel kült uygulamalarına yönelik en önemli verileri kaya yarıkları sunmaktadır (Fig. 10). Kaya bloğunun kuzeyindeki ocakların her iki tarafında yine kuzey yönünde uzanan birer kanalın dışında, geniş derin ve uzun yarıklar kilisenin kuzey nefinin içinde karşımıza çıkmaktadır. Burada kaya zemini düzlenmiştir. Çok düzgün olmayan bu kanalların kısmen doğal olması mümkün olsa da genel olarak insan eliyle şekillendirilmiş olmalıdırlar. Aynı kaya bloğu ve kuzey yönündeki ocaklar gibi olasılıkla bu kaya yarıkları da kutsal alanının başından beri kült uygulamalarına yönelik fonksiyona sahiptiler. Hekatomnoslar Dönemi ile birlikte ocakların işlevlerini kaybettiği ve anakaya bloğunun fonksiyonunun sembolik bir hale 
geldiği, kanalların ise açık kalmaya devam ettiği ve her dönemde işlevlerini devam ettirdikleri düşünülmektedir. Bunu destekleyen en güçlü veri ocakların aksine kanalların içlerinde her dönemden buluntuların ele geçmesidir. Dolayısıyla bu kanallar gerek Hekatomnoslar Dönemi öncesi gerekse de sonrası dönemlerde yer altı tanrılarıyla ilgili kült uygulamalarıyla bağlantılı olmalıdi.

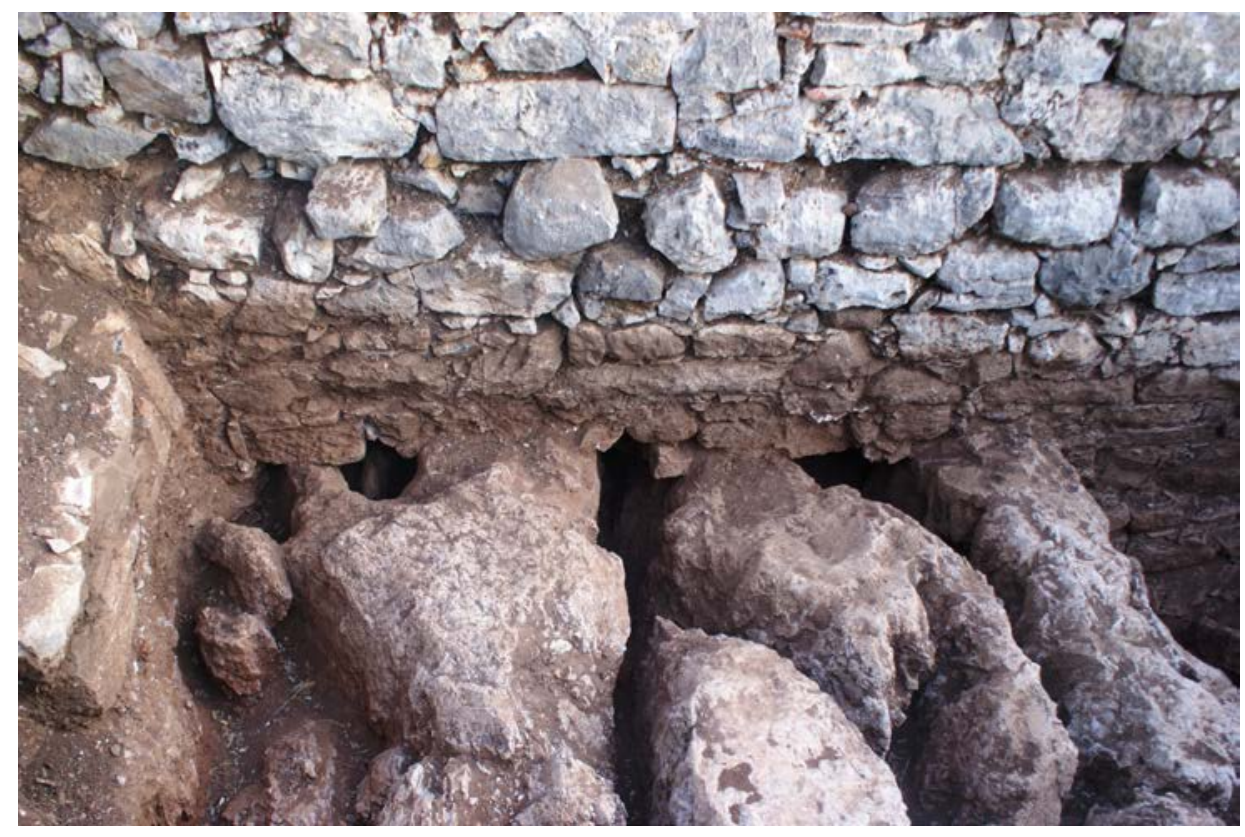

Fig. 10. Kilise orta nefi kuzey duvarı altındaki kanallar

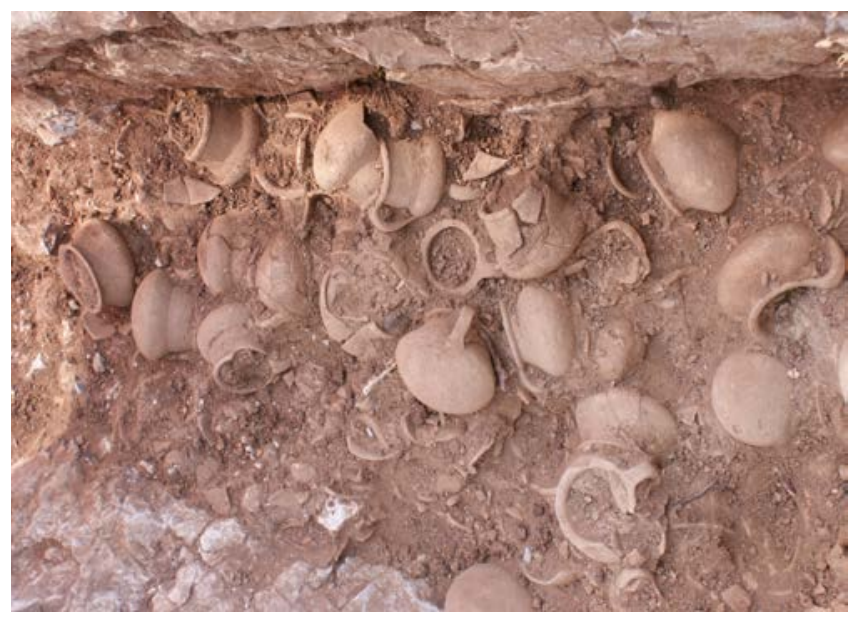

Fig. 11. Chytralar

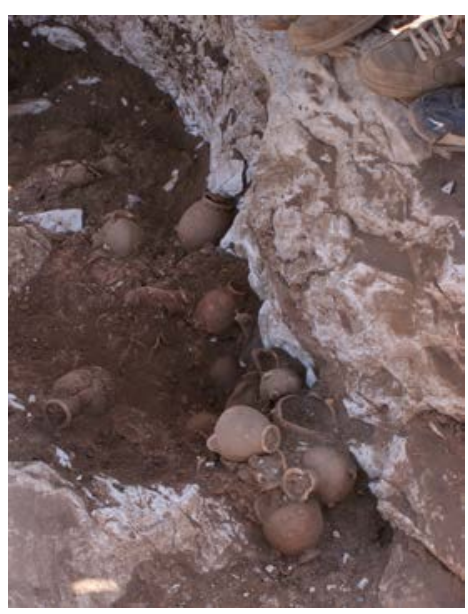

Fig 12. 2 no’lu ocağın üzerindeki hydria depolama alanı

Demeter'in zemindeki yarıklar sayesinde yer altıyla bağlantısı bilinmesine (Kayaya açılmış kanalların en güzel örneklerinden biri Efes’te karşımıza çıkmaktadır. Bk. Soykal-Alanyalı 2005, 319-326) karşın bu yarıklar sadece Demeter için değil genel olarak diğer khthonik tanrılar için de önemliydi (Kült alanlarında karşımıza çıkan benzer karşılaştırma örnekleri için bk. Bulba 2019a). Teras üzerinde çok yoğun buluntular ele geçmesine rağmen, bu adakların bırakılmış olabilecekleri bir alan ya da altar tespit edilememiştir. Belki de adaklar tüm kayalık alana, aynı zamanda da bu kanalların içine bırakılmaktaydı. 


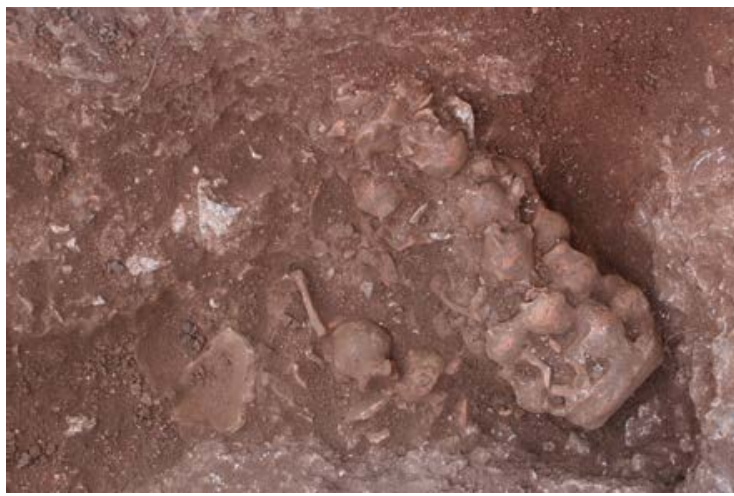

Fig. 13. Çok katlı hydria kernosu ve diğer adaklar

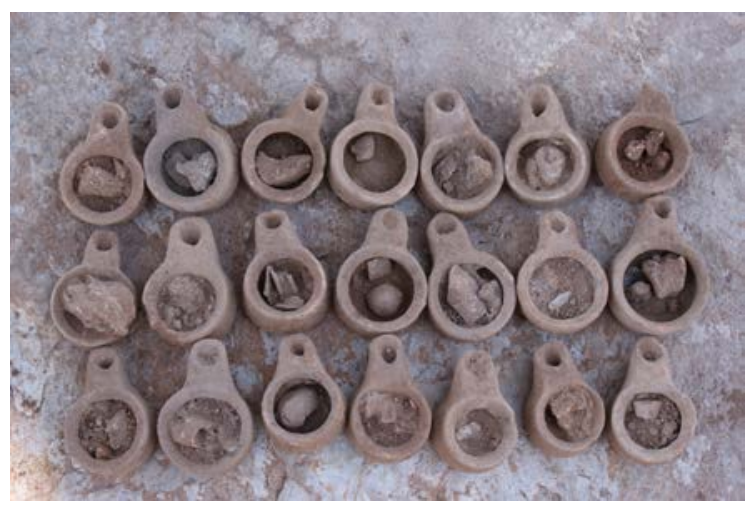

Fig. 14. Kandiller ve içlerindeki kemik adaklar

Olasılıkla Hekatomnoslar Dönemi sonrası merkezi bir fonksiyona sahip olduğunu düşündüğümüz bir başka önemli kanal, anakaya bloğunun batısında yer almaktadır. Bu kanal kıvr1larak doğal anakaya yarığına bağlanır ve olasılıkla yine sıvı sunu yapılmaya hizmet etmiş olmalıdır (Bu kanal kazı başkanı Cengiz Işık tarafından doğal olarak nitelendirilmektedir. Görüşüme göre orijinal halinde kısmen bir doğallık olsa bile insan eliyle işlenerek son hali verilmiştir. Çünkü düzgün bir kıvrım yapmaktadır ve zemini çok pürüzsüzdür. Alana yakın bir bölgede inşa edilen baraj inşaatında çalışan ve ölçüm çalışmaları için alanda bize yardımcı olan, ne yazık ki ismini not etmediğim bir jeoloji mühendisi de bu kanalın doğal olma imkanı olmadığını vurgulamıştır. Kaldı ki tam da doğal yarığa bağlantı noktasında, belirli aralıklarla düzenli bir şekilde açılmış oyuklar bu alana bir cismin (bir süzgecin?) monte edildiğini ve bu alanın insanlar tarafından kullanıldığını göstermektedir). Derin ve doğal bir anakaya oyuğuna bağlanmasıyla yer altı ile ilişkisi net olarak tespit edilebilmektedir. Anakaya yarığının içerisinde yapılan çalışmalarda çok az sayıda seramik parçası dışında herhangi bir arkeolojik kalıntı tespit edilememiştir. Bu durumda bu alanın diğer kanallar gibi bir depolama alanı olarak kullanılmadığı ve sadece sıvı sunular için kullanılmış olduğu anlaşılmaktadır.

Her ne kadar törenlerin uygulanmasına ve adakların bırakılmasına yönelik detaylı bilgi tespit edemezsek de buluntuların gruplar halinde atılmış olmaları, bize bunların bırakılma durumları hakkında da ipucu vermektedir. Adakların döküldüğü alanın eğimli olması nedeniyle bazı karışmalar kaçınılmaz olsa da, adaklar gruplar halinde bu alanlara bırakılmış ya da atılmış olmalıdırlar. Ancak bu işlemin törenlerden hemen sonra mı yoksa bırakılan adakların çok fazla birikmesinden ve yı̆̆ılmaların artmasından dolayı belirli zaman aralıkları ile mi yapıldığını söylemek mümkün değildir. Her durumda bunların toplanması ve depolama alanlarına atılması törenlerin bir parçası olmasa bile kültle bağlantılı olarak yapılmış gibi gözükmektedir.

Kutsal alanda çok sayıda kemik ele geçmesine rağmen çoğu küçük parçalar şeklindedir ve üzerlerinde detaylı bir araştırma henüz yapılmamıştır. Sadece 1 no’lu ocak içerisinde yer alan kemikler kısmen değerlendirilmiş, 2 no'lu ocaktan ele geçen ve sayıca daha fazla olan kemikler üzerine ise henüz çalışma yapılmamıştır. İncelenen kemikler içerisinde yavru, genç ve yetişkin domuzlara ait kalıntılar tespit edilmiştir. Ayrıca hangi hayvanlara ait olduğu belli olmayan çok sayıda kemik de ele geçmiştir (Alpagut 2017, 15-18. Dört yavru domuz, bir genç domuz ve dört yetişkin domuza ait kemikler tespit edilebilmiştir). Bunların içerisinde de olasılıkla başta domuz olmak üzere değişik hayvanlara ait kemikler mevcuttur (İlk grubu inceleyen Alpagut'a batıdaki ocağın içerisinden çıkan kemiklerin fotoğrafları gönderilmiştir. Ancak kendisine göre fotoğraflar üzerinden tespit yapmanın mümkün değildir ve bazıların domuz kemikleri, bunun yanında tavşan ya da başka kemirgenlere ait kemikler de söz konusu olabilir. Alpagut, güvenilir bir tespitin ancak kemiklerin yakından incelenmesiyle mümkün olabileceğini bildirmiştir). 

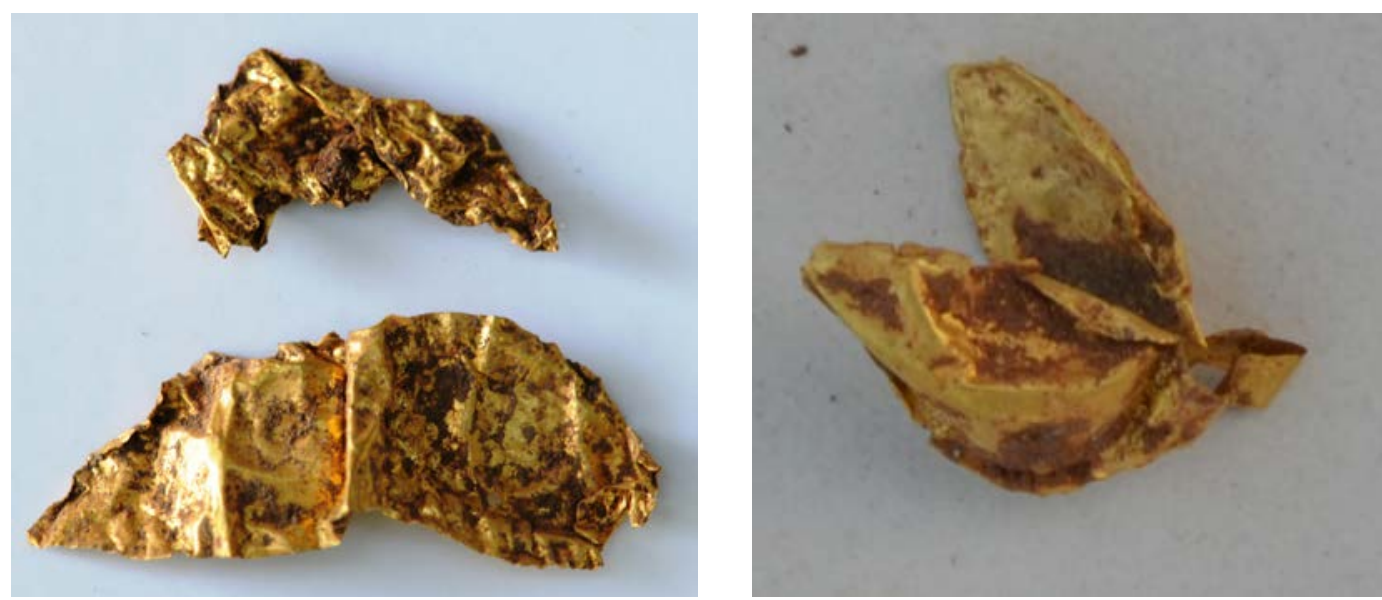

Fig. 15. Altın yapraklar

Ege'nin doğusundaki adalarda ve Batı Anadolu'daki bazı Demeter Kutsal Alanları'nda kemik ve küllerle ilgili tespitler mevcut olmakla birlikte bu kemiklerin detaylı incelenerek yayınlarının yapıldığı merkez sayısı çok azdır. Domuz bu kutsal alanlarda en fazla tercih edilen kurban hayvanı olarak karşımıza çıksa da diğer birçok hayvana ait kemikler de tespit edilmiştir (Kemik buluntuları yayınlanan Demeter Kutsal Alanları ve bu alanlarda hangi hayvanların hangi oranda kurban edildikleri için bk. Karataş 2014, 253, Tablo 2.14.3. Bu tabloya göre domuz kemiklerinin oranı \%30 ila (Mytilene) \%85 arasında (Knossos) değişmektedir. Domuzların yanında koyun, keçi, sığır, balık (en önemli kült merkezlerinden Korinth'de oranı \%30'a ulaşmaktadır) ve diğer hayvanlar (oranları \%1 ila \%15 arasında değişmektedir) adak olarak sunulmuştur). Kaunos'taki gibi bir açık hava kült merkezi özelliğine sahip olan Neandria'daki Demeter Kutsal Alanı'nda da benzer şekilde kemik ve küller ele geçmiştir. Ancak küllerin yakılarak kurban edilen domuz yavrularından geriye kalan küller olup olmadığı kesin değildir. Burada 184 yavru domuz kurban edildiği ve yaklaşı 300 yıl boyunca aktif olan bu kutsal alanda bugünkü bilgiler 1şı̆̆ında yılda birden az yavru domuz kurban edildiği anlaşılmaktadır (Filges \& Matern 1996, 43-86; Karataş 2014, 59-76).

Domuz kemiklerinin yoğun olarak ele geçmesi ilk olarak Demeter kültünü ve onun adına en yaygın kutlanan bayram olan Thesmophoria Şenlikleri'ni (genel bilgi için bk. Nilsson 1955, 463-66; Burkert 1997, 283-292. Thasos’taki thesmophorion için bk. Rolley 1965, 441-483; Clinton 1988, 69-79) akla getirse de bu hayvanlar ucuz olmaları nedeniyle birçok kültte kurban olarak tanrılara sunulmuşlardır. Megara olarak adlandırılan mağara-yarık gibi oluşumlar ile bu hayvanların hangi şartlarda, nerelerde kurban edilmiş olduklarını tespit etmeden bu bayramların kutlanmış olabileceğini söylemek yanlış olur. Hatta Efes'teki Artemis Kutsal Alanı gibi çok önemli bir kült merkezinde ele geçen kemiklerin büyük yoğunluğunun domuzlara ait olması nedeniyle Artemision'da Demeter kültünün de yer alıp almadığı dahi sorgulanmıştır (Forstenpointner 2001, 49-71). Domuz kemikleri genel olarak sadece ocakların içerisinde, yoğunluğu üst bölümde ele geçmişlerdir ve küçük parçalar halindedir. Ocakların üzeri de olasılıkla Hekatomnoslar Dönemi'nde kapatıldığı için bu kemiklerin de önceki evreye ait olma ihtimali yüksektir. Belki de Kaunos'ta, Hekatomnoslar Dönemi öncesi dönemde de domuz ve diğer hayvanlara ait kurbanlar khthonik tanrı ya da tanrılara yönelik kült uygulamalarında kurban edilmişlerdir. Domuz kurbanı Anadolu'da eski bir geleneğe sahiptir ve en erken Hititlerde karşımıza çıkmaktadır. Hititler'in domuzları düşük değerde görmelerine rağmen yoğun üreme özelliği nedeniyle bu hayvanları ritüellerinde kullanmışlardır. Doğurgan domuz bereketli toprağa verildiği bilinmekle birlikte bu törenler hakkında daha fazla bilgi bulunmamaktadır. Hellen kültürünün hakim olduğu bölgelerdeki uygulamalarının bu mantıkla gerçekleştirilmiş olma ihtimali vardır (Clinton 
2005, 178).

Hellas ve Ege'nin Anadolu kıyılarındaki arkeolojik kazılarda ele geçen kemik buluntular hakkında Demir Çağı ve sonrası dönemlere yönelik olarak Reese toplu bir inceleme yapmış ve hayvanlar içerisinde özellikle domuzun, genel olarak da yakılmaksızın Demeter'e kurban edildiği sonucuna varmıştır. Diğer tanrılar için yakılmış kemiklerin analizinden ayrıca koyun, keçi ve büyük baş hayvanların arka bacak bölümünün ve bazen de kuyruk bölümünün adandığı tespit edilmiştir. Domuz kemiklerinin yanmış olarak ele geçtiği durumlarda bunlar genç hayvanlara aittirler ve pişirilmeyip tamamen yanmışlardır. Bazen koyun, keçi ve büyükbaş hayvanların da tamamen yakıldığ 1 örnekler görülmüştür (Reese 2005, 121-123).

Demeter için domuz kurbanı Eleusis'e özgü olmayıp Demeter kültlerinin bütünü için geçerli bir uygulamadır (Burkert 1997, 284). Domuz figürinleri ile domuz taşıyan insanları gösteren figürinler antik dünyadaki tüm Demeter Kutsal Alanları'nın ortak özelliklerindendir. Ancak domuzların megaralara atılması yazıtlarda sadece Atina ve Potniai'da karşımıza çıkmaktadır (Burkert 1997, 284). Arkeolojik olarak ise benzer bir çukur Priene'de ele geçmiştir (Wiegand \& Schrader 1904, 154-5; Schede 1964, 93, Fig. 107, 110). Törene katılan her birey kendi yavru domuzunu getirmek zorundaydı ve yavru domuzların adayanların kendileri gibi temiz olmas1 gerekmekteydi. $\mathrm{Bu}$ hayvanlar adayanların yerine ölüme gitmekteydi. $\mathrm{Bu}$, henüz çok erken dönemlerden beri bilinen bir y1l döngüsünü sembolize etmekteydi. Persephone kaybolduğu zaman yokluk dönemidir, geri geldiğinde ise bolluk ve refah dönemi görülür. Demeter hymnesi Kore'nin geri dönüşünü açık bir şekilde ilkbahar ile açıklar (Burkert 1997, 285 dn. 10).

Kaunos'ta bu ocakların içerisinde hayvan yakma ya da pişirme uygulamalarının olamayacağına göre bu kemiklerin başka bir alandan getirilip atılması akla daha yatkın gelmektedir. Bununla birlikte bu kemiklerin ait olduğu hayvanların hangi alanlarda ve nasıl sunuldukları, hangi amaçla ve nasıl bu alanlara getirildiklerine yönelik elimize herhangi bir arkeolojik kanıt geçmemiştir. Gerek terrakotta figürinlerin, gerek seramik eserlerin, gerekse kandiller ile diğer sunuların tam da bu anakaya bloğunun bulunduğu alandan atılmış olmaları, aynı diğer adaklar gibi bu hayvan sunularına ait bu kemiklerin de bu alana bilinçli olarak atıldıkları şeklinde yorumlanabilir.

Demeter Kutsal Alanları'nda yoğun terrakotta buluntu ele geçmesi alışılmış bir durumdur ve bu özellik Kaunos'ta da karşımıza çıkar. Bunların Demeter Kutsal Alanları'na bırakılmaları Arkaik Dönem ile yaklaşık MÖ 2. yüzyıl arasındadır (Schipporeit 2017, 19-36). Kaunos’ta ele geçen figürinlerin hepsi atılmış durumdadır ve kutlamalar sırasında nereye, hangi şekilde bırakıldıkları tespit edilememişlerdir. Olasılıkla batı yöndeki merdivenlerden çıkılarak kutsal alana girildiğinde karşılaşılan ve kutsal oda olarak düzenlenmiş odada yer alan sunu alanlarına bırakılmışlar ve daha sonra belirli aralıklarla toplanarak tekrar dönüşümlerini engellemek amacıyla depolama alanlarına dökülmüşlerdir.

Demeter için bırakılan adak figürinlerinin çoğunun kadın figürinlerine ait olması sık rastlanan bir durumdur. Demeter kültleri ile genel olarak Thesmophoria Şenlikleri özleştirilmektedir ve bu şenliklere erkekler ya hiç katılamamakta ya da sınırlı bir role sahip olabilmektedirler. Bununla birlikte bu durumun yerel özellik anlamında birçok merkezde farklılaştığ görülmektedir (Kült uygulamaları yayınlanan az sayıdaki merkezden biri de Herakleia antik kentidir. Buras1 yazıtlarla Demeter'e adandığ 1 kesin olan merkezlerdendir. Burada adaklar erkek ve kadınlar tarafından kutsal alana sunulmuştur (Otto 2003, 147-150). Burada ele geçen çok sayıda altar ve sunu çukuru yoluyla kanonik olarak üç çeşit sunu biçimi tespit edilmiştir: 1) Sıvı sunular altara ya da yere doğru dökülmüsşür; 2) Bu kutsal alanda da küllü toprak ile üzerinde yanık izleri olan kemikler bulunmuştur. Yapılan incelemelerde bir ile iki yaş arasındaki domuzlara ait kemikler ve tören yemeğine ait izlerle karşılaşılmıştır; 3) Kurabiye ve ekmek tarzı sunular 
tanrıçaya kanonik olarak bırakılmıştır. Ancak bunun yanında değişik bireysel sunu çeşitleri de görülmektedir (Yazıtlar için bk. Ghinatti 1980, 137-143). Karia'daki Demeter Kutsal Alanları'ndaki erkek sayısının fazlalığı da bu nedenle yerel bir özellik olarak değerlendirilmelidir. Kadın figürinleri içerisinde en yoğun grupları genel olarak hydria ve çocuk taşıyanlar oluşturmaktadır.

Her ne kadar kadın bayramları ve özellikle thesmophoria ilk olarak Demeter ile özleştirilse de, Eileithyia, Kourotrophos, Genetillides ve Aphrodite Kolias kültlerinde de sadece kadınlara özel törenler kutlanmaktaydı. Bunlardan Eileithyia ve Aphrodite erkeklerden de sunular kabul etmişlerdir (Cole 2004, 95). Kaunos'ta da çok sayıdaki erkek figürine rağmen ağırlığın kadınlarda olduğu görülmektedir. Bunların içerisinde en fazla ele geçen grubun hydria taşıyanların alması (Bulba 2019b) bayramlarda suyun ve kadınların önemli bir role sahip olduğunu ya da daha güçlü bir ihtimalle sıradan bir sosyal statüye sahip kadınların bu törenlere katılanlar içerisinde en yoğun grubu oluşturduğunu gösteriyor olmalıdır.

Kaunos'ta ve genel olarak Karia'daki Demeter Kutsal Alanları'nda gerek tip olarak gerekse miktar olarak çok sayıda erkek figürini karşımıza çıkmaktadır. Erkek figürinlerinin Karia'daki Demeter Kutsal Alanları'nda bol miktarda karşımıza çıkması bu bölgenin kendi gelenekleri ile ilişkili olabileceği gibi Demeter için kutlanan törenlerle de bağlantılı olabilir. Thesmophoria Şenlikleri'ne genel olarak erkekler katılmıyor olsalar da Demeter için düzenlenen Karpophoros şenliklerine hem kadınlar hem de erkekler katılabiliyordu (Schipporeit 2013, 30. 'Kadınların katıldığı Thesmophoria kültü daha geç dönemlerde erkeklerin de katılabildiği Karpophoros şenlikleriyle birleştirilmiştir' (Karataş 2014, 268). Karataş, Milet'deki bir yazıttan buradaki törenlere kadınlar yanında erkeklerin de katılabileceği sonucuna varmıştır). Bu figürinlerden bazılarının tanrıları simgelemesi mümkündür. Demeter ile en yakın ilişkili tanrılar olarak karşımıza Hades, Zeus, Hermes, Dionysos ve Herakles çıkmaktadır (Karataş 2014, 40). Karia'nın birçok kentinde ele geçen bu heykeller yoluyla Dionysos'un Demeter ile birlikte doğa tanrısı olarak tapınılmış olması mümkündür ancak Işık'ın $(1980,196)$ ve Schipporeit'ın $(2013,230)$ tespit ettiği gibi kesin bir sonuca ulaşmak için yeterli veri yoktur.

Teras üzerinde yapılan kazılarda çok yoğun miktarda seramik ele geçmesine rağmen (Bulba 2018, 159-179) bunları minyatür hydrialar, khytralar ve kernoslar olarak başlıca üç ana gruba ayırmak mümkündür. Bunların dışında form olarak çok az sayıda kaba ait parçalar ele geçmiştir. İthal seramik yok denecek kadar azdır ve çok küçük parçalar halinde ele geçmeleri yanında kült uygulamalarına yönelik herhangi bir veri sunmamalarından dolayı bunlardan bahsedilmeyecektir.

Khytralar (Fig. 11-12), mezar hediyeleri olmalarının dışında kült kabı olarak ilk defa Fenike dünyasında erken dönemden beri yapı adakları olarak zemin altına bırakılmaktadırlar (Mansel 2003, 129-148). Bu kaplar Demeter Kutsal Alanları'nda nadiren karşımıza çıkmaktadırlar. Gela/Bitalemi'de ele geçen bir grup sırsız kap Orlandini ve Kron tarafindan yuvarlak gövdeli oinochoeler olarak adlandırılmıştır (Kron 1992, 609-650. Fig. 14; Orlandini 1966, 22, Lev. 14, 17 Fig. 1 [özellikle Lev. 17 Fig. 1 çok büyük ihtimalle bir khytra olmalıdır]). Aynı şekilde Locri'deki Thesmophorion'da (Agostino \& Milanesio-Macri 2014, Lev. 1) ve S.Nicola di Albenalla (Cipriani 1989, Fig. 10. 17) Kutsal Alanı'nda bu kap tipine rastlanılmaktadır. Bu örnekler dışında Knossos'taki Demeter Kutsal Alanı'nda da az sayıda khytra ele geçmiştir (Coldstream 1973, Lev. 15).

Khytraların kült kabı olarak kullanılmasında ise ilk akla gelen tanrı Dionysos'tur. Dionysos adına düzenlenen Anthesteria Bayramları'nda bu kült kabının özel bir önemi vardır. Özellikle İonialarla özdeşleştirilen bu bayramda Karialıların (olasılıkla köle olarak) ve khytraların önemli bir rolü vardır (Auffarth 1996, 732-733 s.v. Anthesteria; Burkert 1997, 250 vd.: Karialılarla bağlantılı olarak Karialı kölelerin istisnai olarak bu bayramları kutlamaya izinli olduklarını ya 
da Attika Bölgesi’nin en eski sakinleri olarak Karialıların bu bayramla bağlantılı olabileceklerini yazmaktadır. Ona göre ikinci seçenek daha güçlü bir ihtimaldir. Çünkü Atina'da Trakyalı ve Kelt kölelerin sayısı çok daha fazlaydı. Bir anlatıma göre 'bir zamanlar Attika'nın bir bölümünde Karyalılar oturmaktaydı ve Atinalılar anthesteria bayramlarına başladıklarında onlarla bir anlaşma yaparak onları evlerine aldılar. Bayramdan sonra rastladıkları Karyalılara ise şaka olarak 'Karyalılar dışarı! Anthesteria bayramı bitti' demişlerdir'). Eretria'daki bir pyra içerisinde ele geçen bir chythridion Metzger tarafından diğer buluntularla birlikte Dionysos ile ilgili olarak Anthestreia Bayramları ile ilişkilendirilmektedir (Metzger 1978, 81-87 [MÖ IV. yüzyılın son çeyreği]). Bu yerleşimdeki mezarlardan ele geçen protomlardan Dionysos'un ruhların hakimi olduğu yorumu yapılmaktadır. (Bk. Nillsson 1955, 595-598). Dionysos ile bağlantılı olabilecek bir başka buluntu grubu İsthmia'daki bir tiyatro mağarasında ele geçmiştir (Gebhard 2002, 63-74, öz. 71 Fig. 10. Tiyatro Mağarası. Olasılıkla Dionysos ile bağlantılı olduğu düşünülmektedir). Kaunos örneğinde bu kapların Dionysos'a yönelik olarak kullanılmış olmaları daha güçlü bir olasılık olarak kabul edilebilir. Özellikle, Anthesteria Bayramları'nda olduğu gibi bunlarla yarıklara su serpilmesi, Karialıların eski gelenekten bir halk olarak geriye dönmeye çalışmaları Kaunos'ta da canlandırılmış olabilir. Ancak Karia'daki eş zamanlı olarak benzer buluntularla karşımıza çıkan bu kap formuna diğer Demeter Kutsal Alanları'nda rastlanmaması Kaunos'taki kutsal alanın diğerlerinden farklılaştığı şeklinde kabul edilebilir.

Kaunos'ta en fazla ele geçen buluntu gruplarından birini de minyatür hydrialar oluşturmaktadır (Fig. 13). Dairesel dizinde çok sayıda minyatür vazodan oluşan kernoslar ise khthonik tanrıların tamamı için genel adaklardan bir tanesidir (Rolley 1965, 471-7. Ayrıca krş. için bk. Kossatz-Deissmann 1985, 231-234). Hydriaların Demeter kültlerinde bu kadar yoğun olarak ele geçmesi iki durumla bağlantılı olabilir: Birincisi, su yaşam ve bol ürün alabilmek için mutlaka gereklidir; ikincisi ise birçok kültte su temizlik amacıyla kullanılmaktadır (Cole 1988, 164-165). Su kültsel temizlik için önemlidir ve kaynaklardan belki de minyatür hydrialar içerisinde alınmaktaydı. Suyun bu amaçla kullanımı sadece tanrıçalara ait kültlerde karşımıza çıkan bir uygulamadır (Bammer, Brein \& Wolff 1978, 119 Fig. 4-5). Demeter'e minyatür hydria adanmasının arkasında daha çok bereket kavramı olmalıdır. Olasılıkla bu yol ile tanrıçaya bereketli ürün için istekte bulunuluyordu (Filges \& Matern 1996, 77). Bununla birlikte kaya yarıklarına ve zemine dökülen suyun ölü ruhlarıyla iletişim kurmak ve onların susuzluklarını gidermek gibi bir amacı da olabilir.

Kutsal alandaki kült uygulamalarında suyun önemli bir rolü olmalıdır. En önemli buluntu grubunu seramiklerde minyatür hydriaların, figürinlerde ise hydria kernosu taşıyanlarla birlikte hydria taşıyan kadınların oluşturması tesadüf olmamalıdır. Demeter kültünde su özellikle Thesmophoria'larla ve Eleusis kültüyle bağlantılı olarak ritüel temizlik için kullanılmış olmalıdır (Cole 1988, 161-165; Giebel 2000, 30). Ancak Wolf'a göre su, arınma amacından daha çok tanrılara özel bir sunu olarak kültlerde rol oynamaktaydı. Ona göre etkisini arttırmak için kutsal alanlara girmeden ve kurban sunmadan önce zaten arınma işlemi gerçekleştirilmeliydi (Wolf 2004, 93-128). Demeter'in birçok kutsal alanı kaynaklarla ilişkili olarak karşımıza çıkar. Demeter hymnesinden de anlaşılacağı üzere Antik Dönem'de kadının günlük görevlerinden biri su taş1maktır. Bu nedenle kadın bayramlarında da bu uygulamanın canlandırılması anlamlı olabilir.

Suyun Demeter Kutsal Alanları'nda kullanımının en güzel örneğini Priene'de görmekteyiz (Alan hakkında genel bilgi için Wiegand \& Schrader 1904, 147. Terrakottalar için bk. Töpperwein-Hoffmann 1971, 125-160; Rumscheid 2006, 63-67). Buras1 MÖ IV. yüzyılın ortalarında inşa edilmiştir. Tapınağın girişi doğu tarafta, tapınağın kendisi ise temenosun batı tarafındadır. Burada kuzey duvarına yakın olarak konumlanan bir su havuzu bulunmaktadır. Ele geçen su künkleri burada çatı suyunun toplanmadığını, aksine bir taze su sistemi oluşturulduğunu ortaya koyar (Wiegand \& Schrader 1904, 147-149). Bergama'daki Demeter Kutsal Ala- 
nı'nda da benzer yapısal özellikler izlenmektedir. Yaklaşık olarak Priene ile eşzamanlı olarak inşa edilen kutsal alan bir dağın güney eteğinde bulunur. Buradaki çeşme bugünkü haliyle Erken İmparatorluk Dönemi'ne tarihlenir. Daha erken döneme ait bir yapı sadece umut edilebilmektedir (Bohtz 1981, 15-17).

Korinthos’taki Demeter Kutsal Alanı MÖ VII. ve IV. yüzyıllar arasında devamlı bir gelişim göstermiştir. Kutsal alan üç bölümlü bir teras alanına yayılmıştır. Burada da su kullanımı temel önemi olan uygulamalardan biri olmuştur. Çok sayıda ele geçen hydria ve minyatür hydria dışında aynı zamanda duş köşelerinin oluşturulması önemli bir kanıt olarak karşımıza çıkar (Bookidis \& Fisher 1972, 284; 1974, 272; Cole 1988, 165 dn. 83).

Antik dünyanın en bilinen Demeter kült merkezi olan Eleusis aynı zamanda kült uygulamaları hakkında en geniş bilgiye sahip olduğumuz bir kutsal alana ev sahipliği yapar (Mylonas 1961, 224-285; Kerenyi 1962, 39-55; Clinton 1992, 59-63; Dewailly 1992, 146; Hinz 1998, 148; Giebel 2000, 30). Kutsal alanın kuruluşu Myken Dönemi'ne kadar geri gitmektedir. Propylon biçimli girişin hemen ön tarafında Kallikhoros Kuyusu yer almaktadır. Eleusis'te de aynı şekilde Demeter Kutsal Alanı'nı sınırlayan kutsal bölümde bir başka tanrıça olan Artemis Propylaia'ya tapınımı karşımıza çıkar. Kuyunun açılması MÖ VI. yüzyılın ikinci yarısına tarihlendirilir. Eleusis'te hydrophoroslar ele geçmesine rağmen suyun doğrudan kültle ilgili kullanımına yönelik bir veri yoktur. Ancak alanın giriş bölümünde yer alan bu su yapısı diğer kutsal alanlardaki alana girişte temizlenme hizmetine yönelik olarak yapılmış olabileceğini ortaya koyar (Mylonas 1961, 97-99).

Kaunos'a baktığımızda bu kadar yoğun hydria, hydrophoros ve sadece normal örnekleri yanında sadece Kaunos'ta karşımıza çıkan çok katlı hydria kernosu (Fig. 13) taşıyan figürinlerin (Iş1k 2000, 233 Fig. 4) görülmesi nedeniyle bu kült için suyun çok önemli bir role sahip olması gerektiğinden yukarıda bahsedilmişti. Ancak Kaunos'ta kutsal alan içerisinde herhangi bir su kaynağı veya suyun getirildiği bir sistem karşımıza çıkmaz. Bununla birlikte terasın batı yönünde, çok uzak olmayan bir mesafede büyük bir sarnıç bulunmaktadır. Bu sarnıcın kentin su ihtiyacını karşılamaya yönelik mi yoksa, Demeter Kült Alanı için mi inşa edildiğini kesin olarak söylemek zordur. Belki de bu iki amaca birlikte hizmet etmekteydi. Ancak daha çok kültle bağlantısını ortaya koyabilecek bir detaydan bahsetmek yerinde olacaktır: Kutsal alana batı yönde ulaşımı sağlayan çok özenli yapılmış olan basamaklardan ve merdiven ile Demeter Kutsal Alanı'na giriş yapılmaktaydı. Burada dikkat çeken nokta merdivenin giriş bölümünde kesilmeyip özenli bir şekilde anakayanın izin verdiği noktaya kadar devam etmiş olmasıdır. Anakayaya aynı şekilde özenle işlenen bu kısımlarda anakaya boşlukları kesme bloklarla özenli bir şekilde dolgulanmıştır. Normalde merdivenin giriş alanına yetecek kadar uzatılması gerekirken özenli bir şekilde yukarıya doğru uzatılması ritüelin ilk önce bu sarnıca ulaşarak arınma işlemi yapılması ile başladığı düşünülebilir. Zira üst bölümde bu merdivenden ulaşmayı gerektirecek başka herhangi bir yapı mevcut değildir. Olasılıkla ilk önce sarnıca uğranıyor, hydrialar ve kernoslar suyla doldurulup arınma işlemi yapıldıktan sonra kutsal mekana giriş yapılıyordu. Gerek hydrialardan, gerekse khytralardan ve kernoslardan suyun zemine açılan ya da ulaşan kanallara dökülerek sunu yapılmış olması güçlü bir olasılıktır.

Karia'daki Demeter Kutsal Alanları'nın ortak özelliklerinden birisi de çok fazla sayıda kandile ev sahipliği yapmalarıdır ve bu durum Kaunos'ta da karşımıza çıkar. Domuz kemikleri ile birlikte bu adaklar Thesmophoria Şenlikleri'ni akla getirmektedir. Bu bayramlar gece de kutlandığ 1 için kandil buluntularının ele geçmesi, üstelik de sayılarının çok fazla olması normal bir durum olarak kabul edilebilir. Ancak İonia'daki kutsal alanlarda üstelik de Priene ve Bergama gibi Thesmophoria Şenlikleri'nin yapılmış olma ihtimali çok yüksek olan merkezlerdeki Demeter Kutsal Alanları'nda kandil buluntularının eksikliği bu alanlarda anılan törenlerin yapılmadığı veya gece kutlanmadığı anlamına gelmemektedir. Aynı şekilde Karia'daki Demeter 
Kutsal Alanları'ndaki yüksek kandil sayısı da Thesmophoria Şenlikleri'nin Karia'da kutland1ğını ve gece kutlamalarının yapıldığını göstermez. Sağlam kandil sayısının 60.000'in üzerinde olduğu Kaunos'ta ele geçen buluntuların neredeyse tamamı minyatür kandillere aittir ve bunların bazılarının içlerine bir el parmağı zorlukla girebilmektedir (Varkıvanç bu alandan çıkan kandilleri incelemiştir. İncelediği yılda yaklaşık 20.000 civarında olması gereken kandil sayısı kazıların devam etmesiyle birlikte oldukça artmıştır ve sadece sağlam olanların sayısı 60.000'e ulaşmıştır. Kırık olanlarla birlikte kazısı yapılamayan alanlarda da ele geçmeleri olasıllğı göz önüne alındığında 100.000'in üzerinde adak kandilinden bahsetmek abartı olmayacaktır. Bununla birlikte kandil tiplerinde önemli bir farklılık görülmez. Kandiller için bk. Varkıvanç 1998, 87-96; Bulba 2019, 31-41). Hiçbir örnekte de yanma izi tespit edilememiştir. Bu nedenle bu kandillerin bu alana sembolik adak olarak bırakıldıkları daha yüksek bir olasılıktır.

Normal büyüklükteki kandil sayısı yok denecek kadar azdır. Az sayıda da kandil kernosu ele geçmiştir. Bu kandillerin törenlerde hangi amaçla kullanıldıkları ve hangi alanlarla bırakıldıkları hakkında kesin bilgiye sahip değiliz. Ancak diğer buluntular gibi kandil buluntularının da bazen karışsalar da kutsal alanın girişinde oluşturulmuş bölümlerde ayrı bir bölüme adak olarak bırakıldıkları ve işlevlerini tamamladıktan sonra atıldıkları anlaşılmaktadır. Bu alandaki kült uygulamalarıyla ilgili olarak gözlenen tespitlerden bir tanesi de minyatür kandillerin iç kısımlarına parçalanmış kemikler konularak bırakılmış olmasıdır. Bu durum teras üzerinde her zaman karşımıza çıkmasa da özellikle orta nefin güney bölümünde ele geçen kandillerin birçoğunun içerisinde tespit edilmiştir. Bu durumun tesadüf olamayacağı anlaşılmaktadır. Hatta bazılarının içine çok büyük kemikler boşluk kalmayacak şekilde zorla sıkıştırılmıştır (Fig. 14). Bu işlemin amacını tam olarak tespit etmek mümkün olmasa da Demeter'in Persephone'yi bulmasında yardımcı olan domuzla ilişkili olabileceği düşünülebilir (Örneğin Herakleia'dan ele geçen ve Demeter'i betimliyor olması gereken bir kadın figürini sol kolu üzerinde domuz, sağ elinde ise meşale tutmaktadır [bk. Otto 2007, 308 Fig. 4]. Burada görülen meşale-domuz ikilisi Kaunos’ta kandil-domuz kemiği ikilisi şeklinde karşımıza çıkıyor olabilir). Belki de bu kentte - eğer kutlandıysa - Thesmophoria Şenlikleri'nde domuz kalıntılarının tohumlarla bereket için karıştırılmasından sonra geriye kalan kemiklerin bir bölümü Demeter'e sunulmak istenmiştir. Bu durumda kemikler bereketi ve doğurganlığ olabilir.

Bir başka önemli nokta da ince altın levhaların rulo yapılarak kandiller içinde bırakılmış olmasıdır (Fig. 15). Her ne kadar sadece bir kandilin içerisinde böyle bir rulo in situ olarak geçmiş olsa da kandiller ile birlikte ele geçen diğer üç rulonun da kandiller içerisinde adanmış olduklarını kabul etmek mümkündür. Bunların sayısının az olması altının maddi değeri ile bağlantılı olmalıdır. Bunun yanında bazı kutsal alanlarda altın ve kurşun levhalar üzerine göz kulak gibi uzuvlar çizilerek adanmış olması, Demeter'in iyileştirici özelliği ile bağlantılı olarak yorumlanmaktadır. Bunlardan bazısı özel kehanet içeren yazıtlara sahiptir (Zuntz 1971, 277286; Priene'de de Kybele Kutsal Alanı'ndaki küllü alan içerisinde bol miktarda kemik parçacığı ile minyatür kaplar ve altın bir yaprak ele geçmiştir. Bk. Wiegand \& Schrader 1904, 171). Her ne kadar Kaunos'taki altın levhalar üzerinde bu tarz betimlemeler tespit edilmediyse de adaklarının çok büyük oranda ucuz ve basit özelliğe sahip olduğu bu kutsal alana altın gibi pahalı bir ürünün rulo yapılarak adanmasının mutlaka özel bir nedeni olmalıdır. Demeter yanında altın yapraklar Dionysos kültüyle bağlantılı olarak da karşımıza çıkar. Üzerlerine bir çeşit yeraltı geçitleri çizilmesiyle ölülerin Hades’te kaybolmamaları amaçlanıyordu (Giebel 2000, 74 dn. 92).

Tüm bu buluntu grupları ve bunların sayısının fazlalığı, bu alanda yoğun kutlamaların gerçekleştirildiğini ortaya koymaktadır. Yazıtlardan ve arkeolojik kalıntılardan Demeter Kutsal Alanları ile ilgili birçok bayram ve tören tespit edilebilmektedir. Arkeolojik kalıntılar bu 
tanrıçaya kanlı (hayvan kurbanı) ve kansız (libasyon, değişik bitkisel sunular) olmak üzere iki ana grupta sunu yapıldığını ortaya koymaktadır (Karataş 2014, 28). Pausanias Hellas'taki Demeter'e ait bazı kutsal alanlarda sunuların nasıl yapıldığ 1 dair bilgiler verir: Eleusis'te kurabiye (Paus. I. 28. 6), Mykalessos'ta meyveler (Paus. IX. 19. 4), Argos'ta yanmakta olan meşaleler bir çukura atılmaktadır (Paus. 2.22.4). Mysterium törenleri ayrıca Phenos'daki Demeter Açık Hava Kutsal Alanı'nda (Paus. VIII. 15. 1-2) gerçekleştirilmiştir. Potniai'de ise genç domuzlar Demeter'e ait bir kutsal mekanda bir çukura atılmaktaydılar (Paus. IX. 8. 1). Karataş, Pausanias'ın aktardıklarından yola çıkarak mysterium törenleri de dahil olmak üzere bu yemek sunuları ile kemik ve küllerin varlığı nedeniyle yakma sunuların Neandria' daki açık hava kutsal alanında da gerçekleştirilmiş olması gerektiğini düşünmektedir (Karataş 2014, 350-352).

Domuz figürinleri, domuz taşıyan kadınlar ve en önemlisi de bol miktarda ele geçen domuz kemiği akla Kaunos'taki Demeter Kutsal Alanı'nda tanrıça adına kutlanan en yaygın bayram olan Thesmophoria Şenlikleri'ni getirmektedir. Burada yapılan törenlere erkeklerin katılıp katılmadığı konusunda sadece figürinler yardımıyla bilgi sahibi olabiliriz. Çok sayıda ele geçen erkek figürini ellerinde simge tutmadıkları için genel olarak adak sunan ölümlüleri sembolize ediyor olmalıdırlar. Her ne kadar (eğer kutlandıysa) Thesmophoria Şenlikleri öncelikle bir kadın bayramı olsa da erkeklerin de bu törenlere katıldıkları hem Hellas hem de Sicilya'daki kutsal alanlarda yapılan tespitlerden bilinmektedir. Demeter'in en ünlü kutsal alanı olan Eleusis'teki mysterium törenlerine erkeklerin yanında köleler dahi katılabilmekteydi (Burkert 1997, 281 dn. 29). Aynı şekilde örneğin Syrakusai'da Kore'nin kaçırılmasını hatırlamak amacıyla yılda bir defa çok sayıda erkek ve kadının katılımıyla büyük bir tören düzenlenmekteydi (Hinz 1998, 2830). Demeter'in iki önemli rolü vardır: Bereket ve ölümden sonraki hayat için daha fazla umut. Demeter hymnesine göre 'bu törenlere katılanlar ölümlü insanlar içinde kutsanacaklardır, ancak katılmayanlar soğuk karanlıkta aynı şansa sahip olamayacaklardır'. Ayrıca Sophokles, törenlerde bırakılan sunularla ilgili olarak "Bu sunuları bırakanlar üç kez kutsanmıştır ve böylece Hades'e gelirler. Sadece onlar için orada hayat vardır, diğerleri için ise orası lanetlidir" demektedir (Burkert 1997, 281). Bu bayramların temeli tarımla ilgili olmalıdır ve buna yönelik kült törenleri Neolitik Dönem'e dek geriye giderek insanlık için göreceli olarak yeni olsa da ölümle alakalı kültler Paleolitik Dönem'e kadar geri gitmektedir (Nilsson 1955, 661). Özellikle erkeklerin bu törenlerde yer alması konusunda Karia kültlerine has yerel bir farklılık söz konusudur ve bu konu hakkında Kaunos buluntuları bize detaylı bilgiler sunmaz.

Gerek Eleusis mysterium törenleri, gerekse Thesmophoria Şenlikleri hayatın döngüsünü sembolize etmektedirler. Eleusis törenlerinde bu bayram genel özellikler bakımından oldukça basit ve ilkeldir ve Simon, bu bayramı "Taş Devri'nden kalma" olarak değerlendirmektedir (Simon 1969, 92). Betimlemeler yoluyla Thesmophoria Şenlikleri'ni kutlamaya gidenlerin domuz yavrularını nasıl taşıdığını bazı eserlerden bilmekteyiz (Kumai'de kabartmalı hydria: Nilsson 1955, 45; Mylonas 1961, Fig. 66; Metzger 1965, 21. Atina adak kabartmas1: Metzger 1965, 38 No 24; Eleusis tanrıçalarına yetişkin bir domuzun kurban edilmesi: Louvre 752 no’lu adak kabartması: Charbonneaux 1963, 121. Daha geniş bilgi ve kaynakça için bk. Burkert 1997, 283-292). Bu bayramların ana sembolü olan domuzlara yönelik en erken buluntulardan birisi Maraton yakınlarındaki Nea Makri'de Erken Neolitik Çağ'a ait bir domuz heykelciğidir (Burket 2011, 29; Theochrais 1956, 24). Ancak tarımın kökeni 'Bereketli Hilal' olarak adlandırılan bölgededir ve hem tarım hem de koyu keçi gibi en önemli evcil hayvanlar Anadolu üzerinden Hellas'a geçmiştir (Burkert 2011, 26. Burkert çok eski ve yerleşik hale gelmiş uygulamaların aralarında önemli zaman ve mesafe farklılıkları olduğundan ve bu boşlukların ancak hipotetik olarak doldurulabileceğinden hareketle değerlendirmede dikkatli olunması gerektiğini ve yeni bulguları beklemek gerektiğini düşünmektedir). Aynı şekilde kayanın kutsal olarak kabul edilmesi ve tapınılması Anadolu'da çok erkene kadar giden bir geleneğe sahiptir (Iş̧1k 2010, 81- 
83; 2013, 207-213). Thesmophoros (kanun yapıc1) Demeter'in en yaygın epitheti olarak karşımıza çıkmaktadır (Demeter'in epithetleri için bk. Karataş 2014, 35). Bu epithet Anadolu'da yaygın olarak Aiolis ve İonia' da karşımıza çıksa da Thesmophorion ay adı olarak sadece Karia kentlerinden bilinmektedir (Karataş 2014, 34). Antik dünyada kentler kullandıkları ayların isimlerini o dönemde kutladıkları bayramlara göre adlandırmışlardır (Johnston 2004, 267). Bu nedenle bir kentte Thesmophoria'nın ay adı olarak karşımıza çıkması, o kentte bu bayramın kesin olarak kutlandığını gösteriyor olmalıdır. Kaunos'ta Thesmophorion'un ay adı olarak karşımıza çıkması nedeniyle (Marek 2006, 35) bu bayramların kutlanıyor olması gerekse de (Teras üzerindeki thesmophoria bayramlarına yönelik izler olduğuna yönelik görüşler için bk. Doyran 2017, 1-14) arkeolojik veriler eksiktir. Schipporeit sadece Priene'deki Demeter Kutsal Alanı'ndaki şenliklerin Thesmophorion olarak adlandırılabileceğini ortaya koymuştur (Schipporeit 2013, 277).

Genel olarak kadınlar tarafından kutlanan ancak bazı durumlarda ve yörelerde erkeklerin de katıldığı anlaşılan bu bayramların temelinde Burkert'e göre yer altı dünyası ile bağlantı kurma, ölüm korkusu ile ailelerin dağılması gibi kaygılar bulunmaktaydı (Burkert 1997, 245). Epigrafik belgelere göre Thesmophoria ve diğer Demeter bayramları Batı Anadolu ve kıyıa yakın adalarda kutlanmıştır. Karataş’a göre, Demeter kültleri Karia için önemli bir role sahiptir. Kendisi ayrıca Karia kentlerinin komşu Dor kültürü ile değil de Girit ile bağlantılı olabileceğini de düşünmektedir (Tartışma ve Karialıların kültürel bağlantıları için bk. Karataş 2014, 462). Yazıtlar, Batı Anadolu'daki Demeter Kutsal Alanları'nda hem kadınlar hem de erkekler tarafindan adaklar sunulduğunu göstermektedir. Ayrıca Demeter Kutsal Alanları'nda hem rahip hem de rahibeler karşımıza çıkmaktadır (Karataş 2014, 126. Yazıtlara göre Demeter Epheos'ta Dionysos ile birlikte tapınım görmüştür. İki tanrıçaya da ortak bir rahip hizmet etmiştir).

Antikçağa çok yaygın bir şekilde kutlanan Thesmophoria Şenlikleri üç gün süreyle kutlanmaktaydı. İlk gün anados olarak adlandırılmakta ve bu günde kadınlar kutsal alana çıkmaktaydı. İkinci gün nesteia olarak adlandırılmakta ve bu günde kadınlar daha çok yas tutmakta ve kalligeneia (iyi doğum) olarak adlandırılan son günde ise kadınlar dans ederek eğlenmekteydi. Ayrıca, kurban, dinsel yemekler ve mağaradan çıkarılan yavru domuz kalıntıları tohumlarla karıştırılmaktaydı. Herodotos'a (VI. 16) göre bu törenlerin kökeni Mısır'a gitmekteydi. Thesmophoria Şenlikleri için en önemli gerekliliklerden biri yavru domuzların atılması için gerekli olan suni veya doğal oyuklar ya da mağaralardır. Bu şenlikler hem Thesmophorion olarak adlandırılan hem de bu ismi taşımayan Demeter Kutsal Alanları'nda kutlanmışlardır. Bu törenler ekim-kasım aylarında (Burkert 1985, 242) açık alanlarda gerçekleştirildiği için kutsal alanlarda bu törenler için herhangi bir yapıya ihtiyaç duyulmamaktaydı (Karataş 2014, 352).

\section{Sonuç}

Kaunos'taki terasındaki kült alanı öncelikle Demeter'e hizmet ettiği ve bu alanda tanrıçanın khthonik özelliklerinin ön plana çıktığı düşünülmektedir. Bunun yanında bu kutsal alanda yine khthonik özellikleri olan Dionysos, Kabirler, Hermes gibi tanrılar için de törenler düzenlenmiş olması mümkündür. Buranın başlangıçta kült alanı olarak seçilmiş olmasının temel nedeni olan anakaya bloğu ise, işlevini zaman içerisinde ocaklarla birlikte kaybetmiş ve belki de sadece Demeter'in kızını beklerken üzerinde oturduğu ve yas tuttuğu bir kayaya dönüşmüştür. Başlangıçtan itibaren ise bu alanda yer aldıklarını düşündügümüz kanallar önemini Doğu Roma Dönemi içlerine kadar korumuş ve burada gerçekleştirilen khthonik tanrıça (Demeter-Persephone) ya da tanrılara (Dionysos, Hermes, Kabirler) ait törenlerde yer altı ile ilişkiler kurmada en önemli rolü oynamışlardı. Buluntuların yoğunluğu ve çeşitliliği, Kaunos'taki bu kutsal alanın Hekatomnoslar Dönemi'nde kentsel değil, bölgesel bir kutsal alana dönüştürüldüğünü düşündürmektedir. 
Genel olarak ise Anadolu'da ve Karia'da Demeter kültünün çok daha erkene gittiği düşünülebilir (Sicilya'daki Demeter-Kore kültünün Karia kökenli olabileceği tartışma için bk. Hinz 1998, 22 dn. 33. Bu kültün Karia ile bağlantısı olabileceğine dair bir efsaneye göre Hades ile Persephone Nysa'da evlenmektedirler. Bk. Kerenyi 1967, 34. Demeter kültünün Karia ile bağlantısı Triopas efsanesinde karşımıza çıkmaktadır: Schwenk 1841, 79; 649-655). Kaunos’ta tarihlenebilir en erken buluntulardan burasının MÖ VI. yüzyıldan itibaren merkezinde kaya yükseltisi bulunan bir kutsal alan bulunmaktaydı ve bu kutsal alan köklerini olasılıkla MÖ II. bin ya da daha öncesine giden bir gelenekten almaktayd. Yine Karia Bölgesi'nde yer alan İasos'ta, kayalık bir alana yapılmış olması ve üzerinde kaya yarıkları bulunmasıyla en geç MÖ VI. yüzyıldan itibaren kutsal alan olarak karşımıza çıkmaktadır (Levi 1967/68, 569-573; Levi 1969, 119-121; Johannowsky 1985, 55-58; Berti \& Masturzo 2000, 218- 220; Bonifacio 2001, 14-16; Rumscheid 2006, 149; Schipporeit 2013, 81-92) ve bu geleneğin Karia'da istisnai bir durum olmadı̆̆ını ortaya koymaktadır. Karataş’a göre kayalık alanlara yapılmış Demeter Kutsal Alanları geleneğini Eleusis'ten daha çok Karia'dan almış olmalıdır. Özellikle Kıbrıs heykellerinden alanın MÖ V. yüzyılda kullanımda olduğunu ve ayrıca önemli bir kült merkezi haline gelmiş olabileceği sonucu çıkmaktadır. İlginç olan nokta, alanda ele geçen iki Kıbrıs heykelciğinden daha geç olanın (olasılıkla V. yüzyılın 2. yarısı) arka yüzü yukarı gelecek şekilde ve başı olmadan batıdaki ocağın üzerine konulmuş olmasıdır (Bulba 2011, 17-30). Bu eser bu alana konulduktan sonra ocağın işlevini kaybettiği ve artık kullanılmadığı anlaşılmaktadır. Teorik olarak bu heykel uzun süre sağlam kalmış olabilir, ancak yine de konulduğu dönemin IV. yüzyıl başlarından sonraya gitme ihtimali zayıftır. Bu durumda Hekatomnoslar Dönemi'nde (Hekatamnos MÖ 392-377, Maussollos 377-353) bu ocaklar (olasılıkla diğeri de) fonksiyonlarını kaybetmiş olmalıdır. MÖ IV. yüzyılla beraber burası Kaunos'a hizmet etmekten daha çok bölgesel öneme sahip bir kült merkezi haline gelmiş olmalıdır. Burada başta Demeter olmak üzere yer altı tanrılarına (khthonia thea) adanan bir kutsal alan olması gerekmektedir (khthonik tanrıçalar olarak öncelikle Demeter ve Persephone kabul edilmektedir. Ancak Hades, Zeus, Ge, Hermes, Hekate ve Aphrodite de khthonik tanrilara dahildir (Schleiser 1997, 1185-1190 s.v. Chthonische Götter). Alanda Demeter adına Thesmophoria veya onun yerel versiyonu bir bayramın kutlanmış olma ihtimali yüksektir. Olasılıkla halen etkileyici bir şekilde korunmuş ve terasa batıdan girişi sağlamak için yapılmış olan merdivenlerden giren halk Küçükkale üzerindeki su sarnıcına gidiyor, burada hydria ve hydria kernoslarını su ile doldurduktan sonra adaklarını girişte oluşturulmuş olan kutsal mekanda belirli bir düzen içerisinde bırakıyor, sıvı sunularını kanallara döktükten sonra teras üzerinde bayramlarını kutluyorlardı. Ancak törenlerin gece de sürdürülüp sürdürülmediği yoğun kandil buluntusuna rağmen belirsizdir. Ayrıca buradaki törenlerin bir gizem töreni olduğunu söylemek de zordur. Duvarların korunmuş olma durumundan günümüzden çok da fazla yüksek olduklarını söylemek zordur ve özellikle tiyatrodan ve palaestra terasından burada gerçekleştirilen törenlerin görülmüş olma ihtimali yüksektir. 


\section{KAYNAKÇA}

Agostino R. \& Milanesio-Macri M. (2014). Il Thesmophorion di Locri Epizefiri. Reggio Calabria 2014.

Alpagot A. (2017). "Kaunos Demeter Kutsal Alanı'ndan Ele Geçen Domuz Kemikleri Hakkında İlk Gözlemler”. Eds. M. Doyran, B. Özen-Kleine, U. Çörtük \& S. Özen, Uluslararası ‘Anadolu'da Demeter ve Diğer Ana Tanrıça Kültleri' Sempozyumu (25-28 Haziran 2014). (2017) 15-18. İzmir.

Auffarth C. (1996) “Anthesteria”. DNP. Cilt 1 (1996) 732-733.

Bammer A. (1998). "Sanctuaries in the Artemision of Ephesos”. Ed. R. Hägg, Ancient Greek Cult Practice from the Archaological Evidence. Proceedings of the Fourth International Seminar on ancient Greek Cult, organized by the Swedish Institute at Athens (22-24 Ekim 1993). (1998) 27-47. Stockholm.

Bammer A., Brein F. \& Wolff P. (1978). "Das Tieropfer am Artemisaltar von Ephesos". Eds. S. Şahin, E. Schwertheim \& J. Wagner, Studien zur Religion und Geschichte Kleinasiens I. Festschrift für F. K. Dörner. EPRO 66 (1978) 107-157.

Berti F. \& Masturzo N. (2000). "Aree di culto ed elementi architettonici di periodo archaico a Iasos (Caria)". Ed. F. Krinzinger, Die Ägais und das westliche Mittelmeer, Beziehungen und Wechselwirkungen 8. bis 5. Jh. v. Chr. Archäologische Forschungen. Bd. 4 (2000) 217- 229.

Bohtz C. H. (1981). Das Demeter-Heiligtum (AvP XIII). Berlin 1981.

Bonifacio R. (2001). "Statuette arcaiche dal santuario di Demetra e Kore”. Bolletino dell'Associazione

Bookidis N. \& Fisher J. E. (1972). "The Sanctuary of Demeter and Kore on Acrocorinth. Preliminary Report, 4”. Hesperia 41 (1972) 283-331.

Bookidis N. \& Fisher J. E. (1974). "Sanctuary of Demeter and Kore on Acrocorinth. Preliminary Report, 5. 1971 - 1973”. Hesperia 43 (1974) 267-307.

Bruns G. (1960). “Umbaute Götterfelsen als kultische Zentren in Kulträumen und Altären”. JDI 75 (1960) 100111.

Bulba M. (2006-2007). “Demeterkult in Kaunos”. Anodos 6-7 (2006-2007) 109-114.

Bulba M. (2010). "Bothroi in Küçükkale in Kaunos”. Belleten 271 (2010) 649-667.

Bulba M. (2011). “Kaunos Demeter Kayalı̆ı̆’ndan Ele Geçen Kıbrıs Heykelcikleri”. Adalya 14 (2011) 17-30.

Bulba M. (2018). "Kaunos Demeter Kutsal Alanı: Seramik Buluntular”. MJH VIII/2 (2018) 159-179.

DOI: $10.13114 / \mathrm{MJH} .2018 .415$

Bulba M. (2019). “Kaunos Demeter Kutsal Alanı: Kandiller”. Phaselis V (2019) 31-41.

DOI: 10.18367/Pha.19002

Bulba M. (2019a). "Kaunos Demeter Kutsal Alanı: Mimari ve İdentifikasyon”. TÜBA-AR 24 (2019) Baskıda).

Bulba M. (2019b). "Kaunos Demeter Kutsal Alanı: Terrakotta Figürinler”. Cedrus 2019/2 (Baskıda).

Burkert W. (1985). Greek Religion. Oxford 1985.

Burkert W. (1997). Homo Necans. Berlin 1997.

Burkert W. (2011). Griechische Religion der archaischen und klassischen Epoche. Stuttgart 2011.

Charbonneaux J. (1963). La sculpture Grecque et Romaine au Musee du Louvre. Paris 1963.

Cipriani M. S. (1989). Nicola di Albanella: Scavo di un santuario campestre nel territorio di PoseidoniaPaestum. Roma 1989.

Clinton K. (1988). “Sacrifice at the Eleusinian Mysteries”. Eds. R. Haegg, N. Maritos \& G. C. Nordquist, Early Greek cult practice. Proceedings of the fifth International Symposium at the Swedish Institute at Athens 1986 (1988) 69-79.

Clinton K. (1992). Myth and Cult. The iconography of the Eleusinian Mysteries. Stockholm 1992.

Clinton K. (2005). "Pigs in Greek Ritual”. Eds. R. Haegg \& B. Alroth, Greek Sacrificial Ritual, Olympian and Chthonian. Proceedings of the Sixth International Seminar on Ancient Greek Cult, organized by the Department of Classical Archaeology and Ancient History, Göteborg University (25-27 April 1997). (2005) 167-179.

Coldstream J. N. (1973). Knossos, the Sanctuary of Demeter. Londra 1973.

Cole S. G. (1988) “The Uses of Water in Greek Sanctuaries”. Eds. R. Hägg, N. Marinatos \& G. C. Nordquist, Early Greek Cult Practice, Proceedings of the Fifth International Symposium at the Swedish Institue at 
Athens 1986 (1988) 161-165.

Cole S. G. (2004). Landscapes, Gender and Ritual Space. Berkeley 2004.

Cronkite S. M. (1997). The Sanctuary of Demeter at Mytilene: A Diachronik and Contextual Study. Yayımlanmamış Doktora Tezi. University College, Londra 1997.

Dewailly M. (1992). Les statuettes aux parures du sanctuaire de la Malophoros à Sélinonte: contexte, typologie et interprétation d'une catégorie d'offrandes. Naples 1992.

Diler A. (2000). "Sacred Stone Cult in Caria”. Ed. C. Işık, Studien zur Religion und Kultur Kleinasiens und des ägäischen Bereichs. Festschirft für Baki Öğ̈̈n zum 75. Geburtstag. AMS 39 (2000) 53-77.

Diler A. (2017). “Account of the Sanctuary Exposed at Caunus City”. Ed. E. Winter, Studien zum antiken Kleiasien III, AMS 16 (1995) 9-20.

Diler A. (2017a). "Kaunos/Kbid Tanrı Kültleri ve Kült Alanları Üzerine Bazı Notlar”. Eds. M. Doyran, B. Özen-Kleine, U. Çörtük \& S. Özen, Uluslararası "Anadolu'da Demeter ve Diğer Ana Tanrıça Kültleri”, Sempozyumu (25-28 Haziran 2014). (2017) 165-194.

Doyran M. (2017). “Kaunos Demeter Kutsal Alanı'nda Thesmophoria Bayramının İzleri”. Eds. M. Doyran, B. Özen-Kleine, U. Çörtük \& S. Özen, Uluslararası 'Anadolu'da Demeter ve Diğer Ana Tanrıça Kültleri”, Sempozyumu (25-28 Haziran 2014). (2017) 1-14

Doyran M. (2017a). “Kaunos Kernosları”. Eds. A. Diler, S. Özen \& U. Çörtük, 50. Yılında Kaunos (2016) 5965.

Filges A. \& Matern P. (1996). "Eine Opfergrube der Demeter in Neandria”. Eds. E. Schwertheim \& H. Wiegartz, Neue Forschungen zu Neandria und Alexandria Troas 2. AMS 22 (1996) 43-86.

Forstenpointner G. (2001). "Demeter im Artemision? Archäologische Überlegungen zu den Schweineknochenfunde aus dem Artemission”. Ed. U. Muss, Der Kosmos der Artemis von Ephesos (2001) 55-61.

Gebhard E. R. (2002). “Caves and Cults at the Isthmian Sanctuary of Poseidon”. Ed. R. Hägg, Peloponnesian Sanctuaries and Cults. Proceedings of the Ninth International Symposium at the Swedish Institue at Athens, 11-13 Haziran 1994 (2002) 63-74.

Ghinatti F. (1980). “Nuovi efori in epigrafi di Erachea lucana”. Eds. F. Krinzinger, B. Otto \& E. WaldePsenner. Forschungen und Funde. Festschrift Bernhard Neutsch (1980) 137-143. Innsbruck.

Giebel M. (2000). Das Geheimnis der Mysterien. Düsseldorf 2000.

Hinz V. (1998). Der Kult von Demeter und Kore auf Sizilien und in der Magna Graecia. Wiesbaden 1998. Iasos di Caria 8 (2001) 14-16.

Iş1k C. (2000). "Demeter, in Kaunos”. BCH Suppl. 38 (2000) 229-240.

Işık F. (1980). Die Koroplastik von Theangela in Karien und ihre Beziehungen zu Ostionien: zwischen 560270 v. Chr. Tübingen 1980.

Işık F. (2010). “Anadolu - Lykia Uygarlığı. Lykia’nın Hellenleşmesi Görüşüne Eleştirel bir Yaklaşım”. Anadolu/Anatolia 36 (2010) 65-125.

Işık F. (2013). “Zur anatolischen Demeter”. Ed. G. Kökdemir, O. Bingöl'e 67. Yaş Armă̆anı (2013) 207-235. Ankara.

Johannowsky W. (1985). “Appunti sul Santuario di Demeter e Kore. Studi su Iasos di Caria”. Venticinque anni di scavi della Missione Archeologica Italiana, Bollettino d'Arte, Suppl. BDA $31 / 32$ (1985) 55-58.

Johnston S. I. (2004). Religion of the Ancient World. Harvard 2004.

Karataş A. M. S. (2014). The Sanctuaries of Demeter in Western Asia Minor and on the Islands off the Coast. Yayımlanmamış Doktora Tezi. Bristol 2014.

Karataş A. M. S. (baskıda). Tarih "Rock-Cut Sanctuaries of Demeter: Cultic Significance of Rocky Outcrops for the Cult of Demeter”. (baskıda).

Kerenyi K. (1962). Die Mysterien von Eleusis. Zürih 1962.

Kerenyi K. (1967). Eleusis: Archetypal Image of Mother and Daughter. Londra 1967.

Kossatz-Deissmann A. (1985). “Apulischer Kernos”. AA (1985) 229-239. 
Kron U. (1992). "Frauenfeste in Demeterheiligtümern: Das Thesmophorion von Bitalemi”. AA (1992) 609650.

Kron U. (1992a). "Heilige Steine”. Eds. H. Froning, T. Hölscher \& H. Mielsch, Kotinos. Festschrift für Erika Simon (1992) 56-70. Mainz.

Levi D. (1967/68). “Gli scavi di Iasos”. ASAtene 45-46 (1967/68) 537-594.

Levi D. (1969). “La mission archéologique italienne de Iasos”. Türk AD 17 (1969) 117-121.

Mansel K. (2003). "Zeremeniolle und rituelle Handlungen bei Baumassnahmen. Zu phönischen-punischen Bauopfern”. Ed. C. Metzner-Nebelsick, Rituale in der Vorgeschichte, Antike und Gegenwart. Tagung Berlin 2002 (2003) 129-148.

Marek C. (2006). Die Inschriften von Kaunos. Münih 2006.

Martinetz D., Karlheinz L. \& Janzen J. (1989). Weihrauch und Myrrhe. Stuttgart 1989.

Metzger H. (1965). Recherches sur l’imagérie athènienne. Paris 1965.

Metzger I. R. (1978). “Die Funde aus den Pyrai”. Eretria. Ausgrabungen und Forschungen 6 (1978) 81-87.

Miles M. M. (1998). The City Eleusinion. The Athenian Agora 31. Princeton 1998.

Muss U. (1983). Studien zur Bauplastik des Archaischen Artemisions von Ephesos. Bonn 1983.

Muss U. (2001). "Vom Mythos zur Archäologie eines Heiligtums: Ein bronzezeitlicher Kopf aus Artemision".

Ed. U. Muss, Der Kosmos der Artemis von Ephesos. ÖAI, Sonderschriften Band 37 (2001) 153-168.

Muss U. (2005). "Early Cults at Ephesos". Eds. D. Katsonopoulou, S. Soter \& I. Koukouvelas, Ancient Helike and Aigialeia. Archaeological Sites in Geologically Active Regions (2005) 133-151. Atina.

Mylonas G. (1961). Eleusis and the Eleusinian Mysteries. Princeton 1961.

Nilsson M. P. (1955). Geschichte der griechischen Religion. Münih 1955.

Orlandini P. (1966). "Lo Scavo del Thesmophorion di Bitalemi e il culto delle divinita ctnoie a Gela”. Kokalos 12 (1966) 8-35.

Otto B. (2001). "Die hohen Rundaltäre im Demeter-Heiligtum von Herakleia in Lukanian”. Eds. S. Böhm \& K. V. von Eickstedt, Ithake. Festschrift für J. Schäfer (2001) 191-196. Würzburg.

Otto B. (2003). "Opferbräuche im Demeterheiligtum von Herakleia in Lukanien”. Eds. B. Asamer \& W. Wohlmayr, Akten des 9. Österreichischen Archäologentages am Institut für Klassische Archäologie der Paris-Lodron-Universität Salzburg vom 6.- 8. Aralık 2001 (2003) 147-150. Viyana.

Otto B. (2007). "Il santuario di Demetra ad Herakleia in Lucania: Elementi comuni con il mondo indigeno".

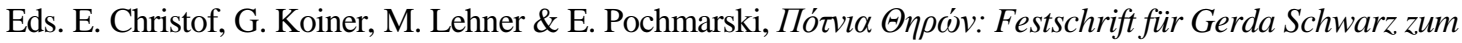
65. Geburtstag (2007) 305-308. Viyana.

Reese D. S. (2005). “Faunal Remains from Greek Sanctuaries: A Survey”. Eds. R. Haegg \& B. Alroth, Greek Sacrificial Ritual, Olympian and Chathonian. Proceedings of the Sixth International Seminar on Ancient Greek Cult, organized by the Department of Classical Archaeology and Ancient History, Göteborg University (25-27 Nisan 1997). (2005) 121-123. Stockholm.

Robert F. (1939). Thymele. Paris 1939.

Rolley C. (1965). "Le sanctuaire des dieux patrôoi et le Thesmophorion de Thasos”. BCH 89 (1965) 441-483.

Rubensohn O. (1955). “Das Weihehaus von Eleusis und sein Allerheiligtes”. JDI 70 (1955) 1-49.

Rumscheid F. (2006). Die figürlichen Terrakotten von Priene. Wiesbaden 2006.

Schede M. (1964). Die Ruinen von Priene. Berlin 1964.

Schipporeit S. T. (2013). Kulte und Heiligtümer der Demeter und Kore in Ionien. İstanbul 2013.

Schipporeit S. T. (2017). "Bildgehalt und Ritualbezug griechischer Votivterrakotten in kleinasiatischen Heiligtümern der Demeter und der Artemis”. Eds. M. Doyran, B. Özen-Kleine, U. Çörtük \& S. Özen, Uluslararası 'Anadolu'da Demeter ve Diğer Ana Tanrı̧̧a Kültteri”' Sempozyumu (25-28 Haziran 2014). (2017) 19-36. İzmir.

Schlesier R. (1997) “Chthonische Götter”. DNP. Cilt 2 (1997) 1185-1190.

Schwenk K. (1841). "Erysichton, Triopas und Demeter”. Zeitschrift für die Alterthumswissenschaft 79 (1841) 649-655. 
Simon E. (1998). Die Götter der Griechen. München 1998.

Soykal-Alanyalı F. (2005). "Überlegungen zu dem Kult von Demeter und Kore im sogenannten Felsspalttempel in Ephesos”. Eds. B. Brandt, V. Gassner \& S. Landstätner, Synergia. Festschrift für F. Krinzinger (2005) 319-326. Wien.

Theochrais D. R. (1956). "Nea Makri. Eine grosse neolithische Siedlung in der Nähe von Marathon”. AM 71 (1956) 1-29.

Töpperwein-Hoffmann E. (1971). "Die Terrakotten von Priene”. IstMitt 21 (1971) 125-160.

Varkıvanç B. (1998). "Miniaturlampen aus dem Demeterheiligtum in Kaunos". Adalya 3 (1998) 87-96.

Wiegand T. \& Schrader H. (1904). Priene. Ergebnisse der Ausgrabungen und Untersuchungen in den Jahren 1895-1898. Berlin 1904.

Wolf R. H. W. (2004). Mysterium Wasser: Eine Religionsgeschichte zum Wasser in Antike und Christentum. Göttingen 2004.

Zäh A. (2001). “Das spätantike und byzantinische Kaunos”. IstMitt 51 (2001) 403-413.

Zäh A. (2001a). “Die Kirchen von Kaunos”. Türk AED 2 (2001) 111-116.

Zuntz G. (1971). Persephone. Three Essays on Religion and Thought in Magna Graecia. Oxford 1971. 